\title{
The Interpretation of Null Subjects in a Radical Pro-drop Language: Topic Chains and Discourse-semantic Requirements in Chinese
}

\author{
Mara Frascarelli ${ }^{1}$, Marco Casentini ${ }^{2}$ \\ University of Roma Tre ${ }^{1}$ \\ Sapienza University of Rome ${ }^{2}$
}

\begin{abstract}
Based on original data collected through an online experiment, evidence is provided in this paper that the interpretation of null subjects in a radical pro-drop language like Chinese relies on the topic criterion proposed for consistent and partial prodrop languages (Frascarelli 2007 and Frascarelli 2018), thereby supporting the theory that the null subject parameter implies an information-structural strategy for interpretation. Nevertheless, radical Chinese shows specificities that must be integrated in this theory for a comprehensive account. In particular, even though silent topic can start chains (consistent with the topic criterion), data show a significant preference for overt and local topics as antecedents. This locality requirement thus integrates phonological visibility in a general syntactic condition (minimal overt link condition), proposing an interesting parallel with the properties shown by partial pro-drop languages (Frascarelli and Jimenez-Fernandez in press). The present investigation also contributes to outline the structural differences existing between adverbial clauses in Chinese, supporting a distinction between central and peripheral adverbial clauses (Haegeman 2012). Specifically, while temporal and conditional clauses show the properties of nonrestrictive relative clauses, this is not the case for concessive clauses, which merged as subordinate clauses in either the C-domain or the high split-TP area. Differences between temporal and conditional clauses are attributed to the presence of an overt operator in the latter, and the pre-matrix position of adverbial clauses is explained in the light of their discourse role as frame-setters (Krifka 2007).
\end{abstract}

\section{Keywords}

aboutness-shift topic, null subject, radical pro-drop, topic chains, adverbial clauses

Studies in Chinese Linguistics, Volume 40, Number 1, 2019, 1-46 DOI: 10.2478/scl-2019-0001 (C)2019 by T.T. Ng Chinese Language Research Centre, Institute of Chinese Studies, The Chinese University of Hong Kong 


\section{Introduction}

\subsection{Radical pro-drop languages: An overview}

The notion of "radical" pro-drop languages (also "discourse" pro-drop languages) is generally used to refer to languages that do not realize any verbal inflection and can leave the subject, as well as the object, unexpressed (cf. D'Alessandro 2015).

Many studies have been recently dedicated to this type of pro-drop. According to Biberauer et al. (2010), a crucial role in these languages is played by the total absence of agreement marking as this property is argued to "facilitate" both subject and object dropping. To support this claim, the authors resume three generalizations put forth in the literature.

They take the so-called discourse pro-drop generalization from Tomioka (2003), according to which all languages allowing discourse pro-drop also allow (robust) bare NP arguments since "null pronouns in discourse pro-drop languages are simply the results of NP-deletion/NP-ellipsis without determiner stranding" (Tomioka 2003: 336). The second generalization is taken from Saito (2007), where it is suggested that a single covert grammatical mechanism allows for radical prodrop and argument ellipsis. Specifically, this mechanism involves covert copying of elements into argument positions from a set of discourse-given entities, and the precondition for this covert operation is the lack of surface agreement triggers. Finally, Biberauer et al. (2010) refer to Neeleman and Szendrői $(2007,2008)$ who treat fully specified nominals as $\mathrm{KPs}^{1}$ and posit an operation of contextfree KP deletion. The authors claim that in languages with inflectional pronoun morphology, such context-free deletion is blocked by the elsewhere condition ${ }^{2}$ and sustain that radical pro-drop only occurs in languages whose pronouns are agglutinating for case, number, or some other nominal feature. The correlation between the morphology of pronouns and the availability of radical pro-drop can be derived from the three assumptions given in the following:

(1) a. Null arguments are regular pronouns that fail to be spelled out as PF.

b. Spell-out rules for pronouns might target non-terminal nodes, as well as terminals.

c. Potential competition between different spell-out rules is regulated by the elsewhere condition.

The interpretation of null subjects (henceforth NSs) in Chinese is also dealt with in Huang (1989). It is argued that the lack of a system of (overt) agreement does not pose an important problem for the identification of null arguments in general, but

1 According to Neeleman and Szendröi (2007), the KP (case phrase) is argued to dominate the extended nominal projection of a DP.

2 In Neeleman and Szendröi (2007), the elsewhere condition is formulated as given in the following:

(i) Let $\mathrm{R}_{1}$ and $\mathrm{R}_{2}$ competing rules have $\mathrm{D}_{1}$ and $\mathrm{D}_{2}$ as their respective domains of application. If $\mathrm{D}_{1}$ is a proper subset of $D_{2}$, then $R_{1}$ blocks the application of $R_{2}$ to $D_{1}$. 
only for the identification of NSs, since "while NSs might be regarded as genuine null pronouns (pro's), a null object is best analyzed as a variable A'-bound by an operator that is itself null" (Huang 1989: 187). Hence, according to Huang, NSs and null objects are different entities and a proper representation of a sentence like (2) is given in (3) (from Huang 1989: 187):

(2) Zhansan shuo [Lisi kanjian e le]
Zhangsan say Lisi see
'Zhangsan said that Lisi saw (him).'

[OP ${ }_{i}$ [Zhangsan shuo [Lisi kanjian $\mathbf{e}_{\mathbf{i}}$ le]]]

On the other hand, according to a number of recent studies (in different frameworks), both NSs and null objects are regular pronouns that simply fail to be realized at PF; hence, a null argument can be identified through a context analysis (cf., among others, Zheng 2001; Xu 2005; Song 2009; Yuan 2014).

Taking these proposals as a background for the present analysis, this work is aimed to deal with the acceptability and interpretation of NSs in Chinese from a formal perspective, adopting an integrated framework of analysis in which syntax and discourse grammar intersect and provide crucial insight for a comprehensive explanation of antecedence relations. In particular, we assume the theory of Frascarelli $(2007,2018)$ on the interpretation of NSs in consistent and partial prodrop languages, ${ }^{3}$ so as to check the feasibility of its application to a radical prodrop language like Chinese. Details on theoretical assumptions and the present experiment are given in the following sections.

\subsection{Topic criterion and the formation of topic chains}

Based on an interface analysis of spoken corpora, in works of Frascarelli (2007, 2018), there is evidence that the interpretation of a referential pro depends on a matching relation with a specific type of topic: the so-called Aboutness-shift (A)-Topic.

Following the typology of Frascarelli and Hinterhölzl (2007), the A-Topic is merged in the highest topic position in the split C-domain (cf. Rizzi 1997 and subsequent work), namely, ShiftP, whose head is specified for the [aboutness]; [shift] features. Consequently, the A-Topic is endowed with the discourse property of proposing "what the sentence is about" (using Reinhart's 1982 words). Therefore, from a conversational dynamics viewpoint, the A-Topic must be considered a conversational move, insofar as the selection of a topic is a speech act itself (cf. Krifka 2001: 25). In particular, it is an initiating speech act providing the "entry" under which the subsequent proposition (an assertion, a question, a

3 Notice that the approach of Frascarelli (2007) has been implemented and validated in a number of typological different languages like Somali (Puglielli and Frascarelli 2009), Spanish (JiménezFernández 2016), Finnish (Frascarelli 2018), Romanian and Russian (Frascarelli 2017a) and Old English (Gelderen 2013). 
command, etc.) will be stored (the so called "file card", cf. Reinhart 1982; Heim 1982). Importantly, this qualification implies that the realization of an A-Topic is restricted to root clauses, since only root clauses are endowed with illocutionary force. The following Interface Root Restriction is therefore proposed in Bianchi and Frascarelli (2010):

(4) Interface Root Restriction (Bianchi and Frascarelli 2010, [41])

Information Structure phenomena that affect the conversational dynamics (CG management) must occur in clauses endowed with illocutionary force that implement a conversational move.

Given this picture and the assumption that every predicational (i.e., non-thetic) sentence must have a topic (cf., among others, Kuroda 1965; Lambrecht 1994; Krifka 2007; Miyagawa and Saito 2008), the consequence is derived that every root (or root-like) clause must realize an A-Topic in its C-domain. ${ }^{4}$ Nevertheless, when an A-Topic is maintained continuous across sentences, it needs not to be overtly realized in every subsequent $\mathrm{C}$-domain. Topic continuity thus gives rise to the creation of topic chains, a major ingredient in the present analysis since it implies the existence of silent (null) A-Topics allowing for a local antecedent relation between the (continuing) A-Topic and every NS (or weak pronoun; cf. note 5 ) in the following sentence (for details, cf. Frascarelli 2007, 2018). ${ }^{5}$

Given the assumption that the interpretation of pro depends on a local relation with the current A-Topic and A-Topics are only realized in clauses endowed with illocutionary force, we obtain as a consequence that a topic chain can only be started from a root (or root-like) clause. The topic criterion (5) and the topic chain condition (6) are therefore assumed:

(5) Topic criterion (Frascarelli 2007 [35])

a) The high topic field in the $\mathrm{C}$-domain contains a position in which the [+shift] feature is encoded and matched (via agree) by the local (third person) NS.

b) When continuous, the A-Topic can be null (i.e., silent).

(6) Topic chain condition (Frascarelli 2018 [19])

a An A-Topic chain can only be started from a root (or root-like) C-domain.

b The A-Topic heading the topic chain can be silent.

4 As a matter of fact, scholars investigating the structure of Chinese sentences generally agree that it is a topic-comment language, in which a topic is always realized in the initial position (cf., among others, Shi 1998, 2000; Ding 2009; LaPolla 2009; Fu 2011; Sun 2015).

5 The A-Topic can be also "resumed" by means of low-toned DPs. These elements can be part of a topic chain and instantiate another type of topic, namely, the Aboutness Given (G)-Topic. G-Topics can be either merged in the lowest topic position in the C-domain (namely, FamP) or realized in situ (in Spec,TP) in cross-linguistic variation (cf. Bianchi and Frascarelli 2010; Jiménez-Fernández and Miyagawa 2014). Since they are not endowed with a [shift] feature, they are not subject to the IRR (4) and can be realized in all clausal types. 
To conclude this section, consider as an illustration the following passage taken from Bonvino's (2006) corpus of Italian spoken data:

(7) Ce ne sono due come me e un'altra [A-Topic1] che però pro fa più che altro pratica - è lei a scrivere le notizie ed pro è andata lì perché pro voleva far la speaker - pro $_{1}$ è una di Milano, pro è laureata in legge ... poi il capo [A-Topic2] invece a lei pro, non 1'ha presa come speaker ...

'There are two (women) like me and another one who however gets some practice - it's her who writes the news and (she) went there because (she) wanted to be a speaker - (she) comes from Milan, (she) got a degree in Law... however the boss did not take her to be a speaker.'

As we can see, in this passage, the speaker proposes a colleague of hers (un'altra) as the A-Topic of her discourse, and this is signaled by a raising $\mathrm{L}^{*}+\mathrm{H}$ tone, which Frascarelli and Hinterhölzl (2007) have identified as systematically associated with A-Topics. After this introduction, a topic chain is created including four NSs. ${ }^{6}$ Then, the speaker decides to shift the topic to her boss, and to do that, this constituent is realized with the same raising intonation used before to propose her colleague. This newly proposed A-Topic breaks the former chain and creates a new one: from this point onward, all NSs will refer to "her boss."

\section{The experiment}

\subsection{Objective and working hypothesis}

The working hypothesis of the present research is that the topic criterion (5) and the topic chain condition (6) can also account for radical pro-drop languages. This means that languages like Chinese also create antecedent relations connecting NSs to A-Topics, which are realized in root (and root-like) clauses and create chains across discourse-linked sentences.

This investigation is therefore intended to check and evaluate this working hypothesis and, in case, provide an explanation for the phenomena that might distinguish radical from consistent pro-drop languages. To this purpose, an experiment has been elaborated and distributed to a large number of native speakers.

\subsection{Structure and informants}

The present experiment basically replicates the survey designed and carried out in Frascarelli (2017a, 2018) for Italian, Finnish, Romanian, and Russian. The objective was therefore to analyze and compare the acceptability and interpretation of NSs (and weak pronouns) in the same clausal types used to evaluate Italian (a fully consistent pro-drop language) and partial pro-drop languages.

6 It should be noticed that, in one sentence, the same referent is proposed as a focus in a cleft sentence (è lei a scrivere le notizie 'it's her who writes the news'), showing that this type of discourse category does not interfere in the topic chain. 
The test was loaded on a dedicated website and distributed online (hence, participation was free and no selection was imposed). We could thus collect 417 questionnaires, even though only 97 of them were completed and could be thus considered for analysis. Although anonymous, the questionnaire included a preliminary section asking for demographic and sociolinguistic information (age, sex, provenience, education, familiarity with linguistics), which is given in detail in Table $1:^{7}$

Table 1 Background data on informants

\begin{tabular}{|l|c|c|c|c|c|c|c|c|}
\hline Total & $\begin{array}{c}\text { Age } \\
\text { (average) }\end{array}$ & \multicolumn{2}{|c|}{ Sex } & \multicolumn{2}{c|}{ Education } & \multicolumn{2}{c|}{ Field } & $\begin{array}{c}\text { Linguistics } \\
\text { competence }\end{array}$ \\
\hline & & $\begin{array}{c}\text { Male } \\
\text { (\%) }\end{array}$ & $\begin{array}{c}\text { Female } \\
(\%)\end{array}$ & $\begin{array}{c}\text { University } \\
\text { (\%) }\end{array}$ & $\begin{array}{c}\text { Other } \\
(\%)\end{array}$ & $\begin{array}{c}\text { Human } \\
(\%)\end{array}$ & $\begin{array}{c}\text { Other } \\
(\%)\end{array}$ & $\begin{array}{c}\text { Yes (\%) } \\
(\%)\end{array}$ \\
\hline 97 & 25 & 31 & 69 & 92 & 8 & 65 & 35 & 67 \\
\hline
\end{tabular}

The questionnaire included 10 conditions, each of which repeated twice to test either an NS or a pronoun in the same clausal type. Specifically, the syntactic conditions in which pro(noun)s have been tested are:

(a) in the complement of a bridge verb,

(b) double embedded under a bridge verb with an intervening third singular pronoun,

(c) double embedded under a bridge verb with an intervening first singular pronoun,

(d) in the complement of a factive verb,

(e) in a temporal adverbial clause,

(f) in the matrix clause of a temporal adverbial clause,

(g) in a conditional adverbial clause,

(h) in the matrix clause of a conditional adverbial clause,

(i) in a concessive adverbial clause,

(j) in the matrix clause of a concessive adverbial clause,

(k) in the adverbial clauses examined with a topic preceding the complex sentence,

(l) in the absence of a c-commanding antecedent, and

(m) in a matrix sentence without an overt topic.

The test included a total of 39 target sentences (provided in the Appendix); 30 of these 39 were provided twice in the questionnaire, both as an out-of-theblue sentence and with a previous context allowing for a clear identification of the proposed antecedent. This device was necessary to evaluate the impact and influence of context in a radical pro-drop language. Target sentences were conveniently distanced and randomized, and importantly, informants could not go

7 As for the area of origin of the participants, most of them (94\%) come from a region where dialects of the Mandarin group are spoken. 
back in the online survey (hence, they could not confront or double-check their former answers).

Acceptability could be expressed on a Likert scale, from 0 to 4 (with 0 being totally unacceptable and 4 totally fine) ${ }^{8}$ Only with a positive evaluation (i.e., either 3 or 4) would a subquestion follow asking for the subject of the action expressed in the target sentence. Alternatives were given, and informants were asked to express a value for each of them.

\section{Acceptability and interpretation in the absence vs. presence of a previous context}

To provide an immediate illustration of the data and relevant results, we compare the evaluation provided for the same sample sentence, first without and then with the context provided. In the tables that follow, acceptability rates of each example are given in percentages for values 4 (considered as "fully acceptable"), 3 ("acceptable") and 2 ("marginally acceptable"). As for interpretation, the value provided refers to the sum of values 3 and 4 .

\subsection{NS embedded under a bridge verb}

The first structural context to be analyzed is the case of a pro sitting in the complement of a "bridge verb." As is known, the complement of bridge verbs has "root-like" properties, insofar as it allows for the realization of a number of phenomena that are only allowed in root contexts and in a subset of root-like subordinate clauses (cf., among others, Emonds 2004; Haegeman 2002; Heycock 2006). One of these phenomena includes the presence of an A-Topic (Bianchi and Frascarelli 2010). Let us then consider sentence (8a) in the following: ${ }^{10}$

$$
\begin{aligned}
& \text { a. Zhangsan shuo _ta yao qu jie ta qizi. } \\
& \text { Zhangsan say pro/3sg have to go pick up } 3 \mathrm{SG} \text { wife } \\
& \text { 'Zhangsan said pro/he has to go and pick up his wife.' }
\end{aligned}
$$

As we can see from the results shown in Table 2, both tokens are considered fully acceptable, with no significant difference concerning interpretation, which definitely depends on the DP Zhangsan, which can be identified as the current A-Topic. We can thus argue that the A-Topic Zhangsan starts a topic chain and

\footnotetext{
8 We preferred to use the notion of "acceptability" rather than "grammaticality" since a Likert scale implies the possibility of a gradient evaluation for the sentences under examination, while grammaticality requires a clear-cut judgment, which could bias the present investigation.

9 According to Erteschik-Shir (2006: 284), the term bridge was coined "to characterize the matrix clause in cases in which extraction out of an embedded clause is licensed."

10 For space reasons, we provide in the same example both the NS and the pronoun version of the same condition. Notice that the "pro" notation was not used in the survey to avoid confusions with the informants (possibly not familiar with linguistic terms). However, it is used for translations (and tables) in the present work.
} 
Table 2 NS/pronoun under a bridge verb

\begin{tabular}{|l|c|c|c|c|c|}
\hline & \multicolumn{3}{|c|}{ Acceptability } & \multicolumn{2}{c|}{ Interpretation } \\
\hline & $\begin{array}{c}\text { Value 4 } \\
\text { (\%) }\end{array}$ & $\begin{array}{c}\text { Value 3 } \\
\text { (\%) }\end{array}$ & $\begin{array}{c}\text { Value 2 } \\
\text { (\%) }\end{array}$ & $\begin{array}{c}\text { Zhangsan } \\
\text { (\%) }\end{array}$ & $\begin{array}{c}\text { Somebody else } \\
\text { (\%) }\end{array}$ \\
\hline$P r o$ & 67 & 20 & 7 & 84 & 3 \\
\hline$T a$ & 71 & 13 & 4 & 82 & 2 \\
\hline
\end{tabular}

allows for the interpretation of both an NS and an overt pronoun sitting in the complement of the bridge verb. ${ }^{11}$

Consider now the following example, in which sentence (8a) is preceded by a context proposing Hongliang as an eligible silent A-Topic in the target sentence, which is different from the overt topic subject in the matrix clause (for space reason, glosses are not given for "repeated" target sentences):

b. Zai huiyi qijian Hongliang turan zhan-qi-lai pao le chuqu. in meeting time Hongliang abruptly stand up run PERF go out 'During the meeting, Hongliang stood up abruptly and ran out (of the room).'

Zhangsan shuo ___ta yao qu jie ta qizi.

'Zhangsan said pro/he has to go and pick up his wife.' (=[8a])

As is shown in Table 3, interpretation judgments greatly differ from Table 2 above. Since the context makes clear that the person who has to take his own wife is not the

11 An SCL reviewer objected that the results shown in ( $8 \mathrm{a}$ and b) are biased by the use of shuo 'say', since this verb might be considered a quote verb. S/he therefore suggested the use of another bridge verb, so as to check and validate relevant acceptability rates. To meet this (and other) request(s), a new survey was proposed to informants, in which the bridge verb juede 'think' was used and the acceptability of sentence given in the following was examined, with and without a preceding context, both with an NS and an overt pronoun:

(i) Zhangsan juede _ta yao qu jie ta qizi.

Zhangsan think $\overline{p r o} / 3 \mathrm{sg}$ have to go pick up 3sg wife

'Zhangsan thinks pro/he has to go and pick up his wife.'

Relevant results show that even though acceptability rates are a bit lower than those in Table 2, an NS is definitely accepted also in the presence of a bridge verb like "think" (cf. the table given in the following). Indeed, with juede an NS is even preferred to an overt pronoun since, as interpretation rates show, the latter triggers obviation creating ambiguity, and this outcome is highly disfavored by informants. On the other hand, the use of an NS clearly "guides" informants to link this element to the A-Topic Zhangsan (88\%) supporting - and validating - the present analysis.

\begin{tabular}{|l|l|c|c|c|c|c|}
\hline & \multicolumn{4}{|c|}{ Acceptability } & \multicolumn{2}{|c|}{ Interpretation (\% for values 3+4) } \\
\hline & & $\begin{array}{c}\text { Value 4 } \\
(\%)\end{array}$ & $\begin{array}{c}\text { Value 3 } \\
(\%)\end{array}$ & $\begin{array}{c}\text { Value 2 } \\
(\%)\end{array}$ & $\begin{array}{c}\text { Zhangsan } \\
(\%)\end{array}$ & $\begin{array}{c}\text { Somebody else } \\
(\%)\end{array}$ \\
\hline \multirow{2}{*}{ No context } & Pro & 36 & 22 & 22 & 88 & 0 \\
\cline { 2 - 7 } & Ta & 36 & 0 & 36 & 80 & 60 \\
\hline \multirow{2}{*}{ Context } & Pro & 36 & 29 & 7 & 29 & 20 \\
\cline { 2 - 7 } & $T a$ & 29 & 22 & 22 & 0 & 29 \\
\hline
\end{tabular}


Table 3 Pro(noun) under a bridge verb with context

\begin{tabular}{|l|c|c|c|c|c|}
\hline & \multicolumn{3}{|c|}{ Acceptability } & \multicolumn{2}{c|}{ Interpretation } \\
\hline & $\begin{array}{c}\text { Value 4 } \\
\text { (\%) }\end{array}$ & $\begin{array}{c}\text { Value 3 } \\
\text { (\%) }\end{array}$ & $\begin{array}{c}\text { Value 2 } \\
\text { (\%) }\end{array}$ & $\begin{array}{c}\text { Zhangsan } \\
\text { (\%) }\end{array}$ & $\begin{array}{c}\text { Hongliang } \\
(\mathbf{\%})\end{array}$ \\
\hline Pro & 27 & 31 & 18 & 19 & 39 \\
\hline$T a$ & 54 & 13 & 18 & 15 & 52 \\
\hline
\end{tabular}

matrix subject Zhangsan (which is therefore a background G-Topic; cf. Frascarelli 2007), the role of the DP Hongliang as a silent A-Topic, merged in the C-domain of the (root-like) complement, must be assumed. This is illustrated in the following:

(9) $\left[_{\mathrm{TP}}\right.$ Zhangsan shuo $\left[_{\text {Shift }}<\right.$ Hongliang $>_{\mathrm{k}}\left[_{\mathrm{TP}}\right.$ pro $_{\mathrm{k}}$ yao qu jie ta qizi $\left.]\right]$

Given the topic chain in (9), we can conclude that Chinese speakers allow for an NS that is linked to an antecedent that is different from the matrix topic-subject, even though acceptability decreases with a difference (for values 4 and 3 ) that is statistically very significant ( $p=0.0003$ ). Furthermore, interpretive data show that Hongliang is not significantly preferred to Zhangsan $(p=0.6650)$ : this shows that, despite the context, speakers are confused when the A-Topic is silent. On the other hand, the structure illustrated in (9) is acceptable when the embedded subject is an overt pronoun and interpretation is driven towards the silent A-Topic. This seems to show that Chinese overt pronouns trigger obviation with respect to the local overt topic-subject, ${ }^{12}$ if an alternative is given in the sentence/context.

Let us consider now the case in which an NS is double embedded in a complex sentence under bridge verbs, with an intervening third person subject:

(10) Zhangsan shuo Hongliang yiwei /ta yinggai mai yi liang che. Zhangsan say Hongliang think pro/3sg should buy one $\mathrm{CL}$ car 'Zhangsan said that Hongliang thinks that pro/he should buy a car.'

Table 4 Pro(noun) double embedded under a bridge verb (yiwei)

\begin{tabular}{|l|c|c|c|c|c|c|}
\hline & \multicolumn{3}{|c|}{ Acceptability } & \multicolumn{3}{c|}{ Interpretation } \\
\hline & $\begin{array}{c}\text { Value 4 } \\
\text { (\%) }\end{array}$ & $\begin{array}{c}\text { Value 3 } \\
\text { (\%) }\end{array}$ & $\begin{array}{c}\text { Value 2 } \\
\text { (\%) }\end{array}$ & $\begin{array}{c}\text { Zhangsan } \\
\text { (\%) }\end{array}$ & $\begin{array}{c}\text { Hongliang } \\
\text { (\%) }\end{array}$ & $\begin{array}{c}\text { Somebody else } \\
\text { (\%) }\end{array}$ \\
\hline Pro & 9 & 13 & 29 & 3 & 12 & 7 \\
\hline$T a$ & 52 & 24 & 18 & 67 & 2 & 7 \\
\hline
\end{tabular}

Table 4 shows that an NS is totally unacceptable in this condition, independent of the presence of two c-commanding subjects and the (theoretic) possibility for the

12 A third person pronoun has an obviative function when, in a given discourse context, it distinguishes a non-salient third person referent from a more salient one (Kibort and Corbett 2010). 
embedded DP to be an A-Topic. As for the pronoun, its evaluation shows the same values attested with simple embedding (cf. Table 3) and a clear preference for the matrix subject as an antecedent (further evidence for its obviative effects). ${ }^{13}$

Since the semantics of the verb yiwei in (10) might affect judgments (Pan, personal communication), we also tried sentence (10) with the verb renwei, ${ }^{14}$ proposing the sentence in the following:

(11) Zhangsan shuo Hongliang renwei ___ta yinggai mai yi liang che. Zhangsan say Hongliang think pro/3sG should buy one $\mathrm{CL}$ car 'Zhangsan said that Hongliang thinks that pro/he should buy a car.'

Table 5 Pro(noun) double embedded under a bridge verb (renwei)

\begin{tabular}{|l|c|c|c|c|c|c|}
\hline & \multicolumn{3}{|c|}{ Acceptability } & \multicolumn{3}{c|}{ Interpretation } \\
\hline & $\begin{array}{c}\text { Value 4 } \\
(\%)\end{array}$ & $\begin{array}{c}\text { Value 3 } \\
(\%)\end{array}$ & $\begin{array}{c}\text { Value 2 } \\
(\%)\end{array}$ & $\begin{array}{c}\text { Zhangsan } \\
(\%)\end{array}$ & $\begin{array}{c}\text { Hongliang } \\
(\%)\end{array}$ & $\begin{array}{c}\text { Somebody else } \\
(\%)\end{array}$ \\
\hline Pro & 23 & 17 & 20 & 43 & 71 & 29 \\
\hline$T a$ & 43 & 11 & 17 & 89 & 68 & 32 \\
\hline
\end{tabular}

As we can see in Table 5, the acceptability of the NS does not increase significantly with respect to $(10)(p=0.2895)$. Nevertheless, the selection of the embedded topicsubject Hongliang as an antecedence for the pronoun increases very significantly $(p<0.0001)$. This result confirms that the complement of a bridge verb is a root-like clause in Chinese as well, and as such, topic chains can be started from there. However, this structural condition is only very marginally accepted, thus

13 An SCL reviewer argues that the low acceptability values attested for (10) might not depend on antecedent relations but on the lack of a connective word such as suoyi 'so'. Following this suggestion, we have tried a new survey inserting suoyi in (10), so as to better connect the two sentences. However, results show that acceptability rates slowly decrease with suoyi, both for the NS and the pronoun, contrary to the reviewer's intuition. The only "improving" effect determined by suoyi in the topic chain concerns the selection of Zhangsan as the antecedent of pro: $75 \%$ against $43 \%$ in Table 4 . Hence, the use of a connective seems to favor interpretation, but not acceptability, supporting the present analysis.

14 The verb yiwei in modern Chinese is generally used to express that some previous notion was mistaken, as is shown in (i), whereas renwei is used to express an opinion after analyzing a specific situation, cf. (ii):

(i) Wo yiwei ta mei you gou, keshi ta you.

1SG think 3SG NEG have dog but 3sG have

'I thought he didn't have a dog, but he has it instead.'

(ii) Ta fashao, kesou, quanshen suantong.

3SG fever cough whole body aching

Wo renwei ta yiding shi de le liuxing ganmao le.

1SG think 3SG definitely be get PERF flu PERF

'He is having fever, coughing, and his all body aches. I think he definitely has gotten flu.' 
confirming the conclusion that a radical pro-drop language prefers chains to be started by overt A-Topics sitting in matrix clauses (a crucial information-structure requirement, which will be resumed later in the discussion).

\subsection{NS embedded under a factive verb}

Let us now consider the condition in which the pro(noun) sits in the complement of a factive verb, as in the following sentence:
a. Zhangsan hen yihan
/ta bu neng gei ta qian.
Zhangsan very regret $\overline{p r o} / 3 \mathrm{sg}$ NEG can give $3 \mathrm{sg}$ money 'Zhangsan regrets that pro/he can't give her money.'

Table 6 Pro(noun) under a factive verb

\begin{tabular}{|l|c|c|c|c|c|}
\hline & $\begin{array}{c}\text { Value 4 } \\
\text { (\%) }\end{array}$ & $\begin{array}{c}\text { Value 3 } \\
(\mathbf{\%})\end{array}$ & $\begin{array}{c}\text { Value 2 } \\
(\mathbf{\%})\end{array}$ & $\begin{array}{c}\text { Zhangsan } \\
(\mathbf{\%})\end{array}$ & $\begin{array}{c}\text { Somebody else } \\
(\mathbf{\% )}\end{array}$ \\
\hline$P r o$ & 54 & 17 & 23 & 96 & 4 \\
\hline$T a$ & 46 & 20 & 23 & 96 & 17 \\
\hline
\end{tabular}

Comparing the data in Table 6 with those reported in Table 2, we can see that no significant difference can be found in the acceptability and interpretation of an NS under a bridge or a factive verb: acceptability scores a bit lower but not significantly $(p=1.000)$, and the matrix topic-subject is the only possible antecedent. On the other hand, the acceptability of a pronoun decreases significantly $(p=0.0460)$, and we surmise that this result can be attributed to a clash between syntax and semantics. As a matter of fact, the meaning of yihan implies that the speaker is sorry for something that is not her/his fault, whereas overt pronouns trigger obviation. However, since no alternative antecedent is proposed to the matrix topic-subject Zhangsan, speakers' judgment is puzzled.

To check this hypothesis, let us consider the judgments given in the presence of a context in which the reader is informed about Hongliang's difficult economic situation (which should lead the reader understand that Zhangsan is sorry about Hongliang's situation): $:^{15}$
b. Hongliang gaosu
Zhangsan ta zuijin you kunnan, Hongliang tell Zhangsan 3SG lately have difficulty

15 In the context, we decided to specify the DP his daughter with a proper name (Sunli) to be sure that the participants could understand that Hongliang is Sunli's father. Furthermore, notice that in the target sentence in (12b), the pronoun $t a$ has been substituted by the proper name (Sunli), in order to avoid the use of two instances of the same pronoun with a different reference (avoiding possible ambiguities). We thank an anonymous reviewer for this suggestion. 
ta shiye le erqie ta nü'er Sunli xiang chuguo xuexi. 3SG lose-job PERF and 3SG daughter Sunli wish go abroad study 'Hongliang said to Zhangsan that he had been having a very difficult period: he lost his job and his daughter Sunli would like to go abroad for her studies.' Zhangsan hen yihan pro/ta bu neng gei Sunli qian. (= [12a])

'Zhangsan regrets that pro/he can't give money to Sunli.'

Table 7 Pro(noun) under a factive verb with context

\begin{tabular}{|l|c|c|c|c|c|c|}
\hline & \multicolumn{3}{|c|}{ Acceptability } & \multicolumn{3}{c|}{ Interpretation } \\
\hline & $\begin{array}{c}\text { Value 4 } \\
(\%)\end{array}$ & $\begin{array}{c}\text { Value 3 } \\
(\%)\end{array}$ & $\begin{array}{c}\text { Value 2 } \\
(\%)\end{array}$ & $\begin{array}{c}\text { Zhangsan } \\
(\%)\end{array}$ & $\begin{array}{c}\text { Hongliang } \\
(\%)\end{array}$ & $\begin{array}{c}\text { Somebody else } \\
\text { (\%) }\end{array}$ \\
\hline Pro & 40 & 23 & 17 & 77 & 32 & 0 \\
\hline$T a$ & 37 & 9 & 29 & 87 & 37 & 6 \\
\hline
\end{tabular}

As is clear from Table 7, the interpretation intended unfortunately did not help to have a different interpretation since informants understood that Zhangsan is sorry because he cannot help Hongliang in such a difficult family situation. We thus obtained an (even stronger) refusal for an obviative overt pronoun.

To propose some interim conclusion, we can say that Chinese speakers allow for NSs in embedded position both under bridge and factive verbs, but judgments show a significant preference for an antecedent that is the overt matrix topicsubject. Silent A-Topics are possible, but with lower acceptability rates, especially if embedded. Consequently, double-embedding NSs are hardly accepted.

Let us now proceed with the analysis of the case in which the pro(noun) is not c-commanded by the intended antecedent.

\subsection{Embedded DP as the intended antecedent}

The questionnaire contained the sentence given in (13), in which the proposed antecedence is totally accepted in pro-drop languages like Italian or Spanish (Frascarelli 2018; Frascarelli and Jiménez-Fernández in press) and partially accepted in partial pro-drop languages like Finnish and Russian (Frascarelli 2017a, 2018):

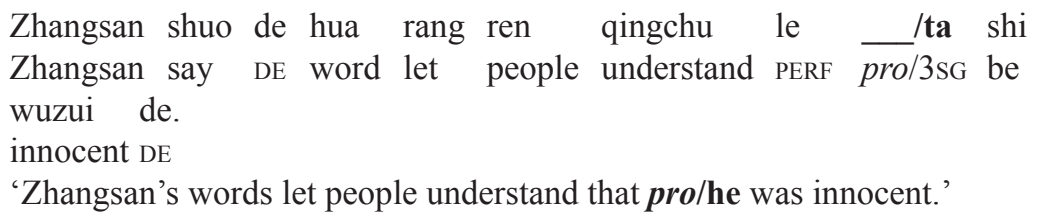

As we can see in Table 8, unlike consistent and partial pro-drop languages, an NS is totally excluded in this syntactic context and it is interesting to underline 
Table 8 Embedded DP as antecedent for pro(noun)

\begin{tabular}{|l|c|c|c|c|c|}
\hline & \multicolumn{3}{|c|}{ Acceptability } & \multicolumn{2}{c|}{ Interpretation } \\
\hline & $\begin{array}{c}\text { Value 4 } \\
(\%)\end{array}$ & $\begin{array}{c}\text { Value 4/3 } \\
(\%)\end{array}$ & $\begin{array}{c}\text { Value } 2 \\
(\%)\end{array}$ & $\begin{array}{c}\text { Zhangsan } \\
(\%)\end{array}$ & $\begin{array}{c}\text { Somebody else } \\
(\%)\end{array}$ \\
\hline Pro & 7 & 6 & 22 & 11 & 4 \\
\hline$T a$ & 43 & 28 & 9 & 84 & 20 \\
\hline
\end{tabular}

that the addition of a context did not improve the result. This means that radical pro-drop is subject to strong structural restrictions, despite its classical definition as a "pragmatic" or "context-dependent" type of pro-drop. ${ }^{16}$

This result strongly supports the conclusions drawn so far, since a sentence like (13) combines two unfavorable conditions for the acceptability of an NS in Chinese, namely: (a) the chain head is a silent A-Topic (since an embedded DP cannot be an A-Topic itself) and (b) the silent A-Topic is not in the local C-domain of the embedded NS, whereas the optimal antecedent for an NS in radical Chinese is an overt, local A-Topic. On the other hand, a silent A-Topic is fine for an overt pronoun, which definitely takes the non-local DP Zhangsan as its antecedent, consistent with its attested obviative effects.

\subsection{First person intervenience in a topic chain}

As is argued in Frascarelli (2018), the presence of first/second person pronouns does not interfere in referential (third person) topic chains. This means that null deictic pronouns enter independent agree relations, and in this respect, Frascarelli follows Sigurdsson (2011: 30, 82) in assuming that the formation of deictic chains relies on a different licensing strategy. ${ }^{17}$ Let us therefore consider what happens in a radical pro-drop language like Chinese:

(14) Zhangsan shuo wo renwei__ta yinggai mai yi liang che. Zhangsan say $1 \mathrm{SG}$ think pro/3sG should buy one $\mathrm{CL}$ car 'Zhangsan said that I think that pro/he should buy a car.'

16 In particular, the context preceding the target sentence (13) was "Sunli is Zhangsan's wife. She was killed one month ago. Zhangsan confirmed that the day his wife was killed he was working in the office when the police contacted him. That's how he found out that his wife was dead," and the values scored for an NS are value $4=12 \%$, value $3=18 \%$, and value $2=24 \%$. Hence, as said earlier, there is no significant improvement in terms of acceptability.

17 Specifically, Sigurdsson (2011) argues that the C-domain contains silent but probing (i.e., syntactically active) "speaker" and "hearer" features, referred to as the "logophoric agent" $\left(\Lambda_{\mathrm{A}},\right)$ and "logophoric patient" $\left(\Lambda_{\mathrm{P}}\right)$, respectively, and that both the logophoric features and the [+aboutness] topic feature are Cledge linkers (CLn). 
Table 9 First person intervenience in a topic chain

\begin{tabular}{|l|c|c|c|c|c|c|}
\hline & \multicolumn{3}{|c|}{ Acceptability } & \multicolumn{3}{c|}{ Interpretation } \\
\hline & $\begin{array}{c}\text { Value 4 } \\
\text { (\%) }\end{array}$ & $\begin{array}{c}\text { Value 3 } \\
\text { (\%) }\end{array}$ & $\begin{array}{c}\text { Value 2 } \\
\text { (\%) }\end{array}$ & $\begin{array}{c}\text { Zhangsan } \\
\text { (\%) }\end{array}$ & $\begin{array}{c}\text { 1st } \\
(\mathbf{\%})\end{array}$ & $\begin{array}{c}\text { Somebody else } \\
\text { (\%) }\end{array}$ \\
\hline Pro & 17 & 23 & 17 & 54 & 14 & 36 \\
\hline$T a$ & 40 & 14 & 11 & 86 & $/$ & 53 \\
\hline
\end{tabular}

As we can see in Table 9, an NS is very marginally accepted in this case, showing again that radical pro-drop is sensitive to locality for topic chains.

More precisely, given also the relevance of overt A-Topics to head topic chains, it can be proposed that radical pro-drop is subject to a restriction that can be traced back to minimality (Rizzi 1990; Manzini 1992; cf. also Villata et al. 2016). This restriction also emerged for partial pro-drop languages (Frascarelli 2018) and has been "revisited" from an interface perspective in Frascarelli and Jiménez-Fernández (in press) and proposed in terms of a minimal overt link condition (MOLC).

However, comparing the interpretive judgments in Table 9 with those reported for double embedding in Table 4, it is interesting to notice that an intervenient first person pronoun is significantly "less disturbing" than a third person DP $(p<0.0001)$, so that the nonlocal Zhangsan is selected by most of the (few) respondents who accepted sentence (14), whereas this was not the case for nonlocal Zhangsan in (10). This supports the idea that first/second person pronouns instantiate different linking relations, and consequently, phi-features have an important role in the formation of topic chains.

This is also (indirectly) supported by the results concerning the overt pronoun. As is shown, its acceptability is rather low, and this result can be attributed to the fact that the matrix topic-subject is the only feasible antecedent. Hence, no obviation effect can be at stake here, while it seems to be a major discourse function for overt third person pronouns.

\subsection{Pro(noun)s sitting in the subject position of matrix clauses}

The acceptability of an NS in matrix clauses shows remarkable variations across languages with partial pro-drop properties (around $87 \%$ in peninsular Spanish varieties, 63\% in Russian, 32\% in Finnish; cf. Frascarelli 2017a, 2018; Frascarelli and Jiménez-Fernández in press), whereas this condition is fully accepted in consistent pro-drop languages like Italian and Romanian (Frascarelli 2017a). Let us then analyze the results obtained with radical pro-drop Chinese:
Zhangsan pei
ta de erzi qu yingyuan kan
dianying.
Zhangsan accompany $3 \mathrm{SG}$ DE son go cinema watch movie

/Ta hen gaoxing.

pro/3sG very happy

'Zhangsan took his son to the cinema. Pro/He is happy.' 
Table 10 Pro(noun) in a matrix clause

\begin{tabular}{|l|c|c|c|c|c|}
\hline & \multicolumn{3}{|c|}{ Acceptability } & \multicolumn{2}{c|}{ Interpretation } \\
\hline & $\begin{array}{c}\text { Value 4 } \\
\text { (\%) }\end{array}$ & $\begin{array}{c}\text { Value 3 } \\
\text { (\%) }\end{array}$ & $\begin{array}{c}\text { Value 2 } \\
\text { (\%) }\end{array}$ & $\begin{array}{c}\text { Zhangsan } \\
\text { (\%) }\end{array}$ & $\begin{array}{c}\text { Zhangsan's son } \\
\text { (\%) }\end{array}$ \\
\hline Pro & 16 & 33 & 24 & 44 & 20 \\
\hline$T a$ & 29 & 27 & 24 & 45 & 20 \\
\hline
\end{tabular}

As Table 10 shows, a matrix NS is possible in Chinese, although marginal, as it is in partial pro-drop languages like Finnish. Nevertheless, the low acceptability values attested for the overt pronoun suggest that partial and radical pro-drop languages cannot be treated on a par, since an overt pronoun is fully accepted in this case in languages like Russian or Finnish. Therefore, we surmise that a solution can be found by examining interpretive data. As we can see, both alternatives score very low, showing that ambiguity is the crucial problem here: both the subject and the object are eligible silent A-Topics, and apparently, this situation is not tolerated by Chinese speakers, who utterly refuse ambiguous statements.

To validate this hypothesis, resting on a cognitive attitude of speakers, let us consider the judgments expressed when the target sentence (15) was preceded by a context, aimed at clarifying the identification of the silent A-Topic:

(16) Zhangsan shang xingqi shengbing le, zhe jian shir rang ta Zhangsan last week fall ill PERF this CL thing let 3SG ganjue nanguo. Xianzai ta quanyu le, ta zhongyu keyi feel sad now 3sg fully recover PERF $3 \mathrm{sg}$ finally can chuqu. go out

'Zhangsan last week was ill and this made him sad. Now he is recovered and he can finally go out.'

Zhangsan pei ta de erzi qu yingyuan kan dianying. __ / Ta hen gaoxing. $(=[15])$

'Zhangsan took his son to the cinema. Pro/He is happy.'

Table 11 Pro(noun) in a matrix clause (with context)

\begin{tabular}{|l|c|c|c|c|c|c|}
\hline & \multicolumn{3}{|c|}{ Acceptability } & \multicolumn{3}{c|}{ Interpretation (\% for values 3 + 4) } \\
\hline & $\begin{array}{c}\text { Value 4 } \\
\text { (\%) }\end{array}$ & $\begin{array}{c}\text { Value 3 } \\
\text { (\%) }\end{array}$ & $\begin{array}{c}\text { Value 2 } \\
\text { (\%) }\end{array}$ & $\begin{array}{c}\text { Zhangsan } \\
\text { (\%) }\end{array}$ & $\begin{array}{c}\text { Zhangsan's son } \\
\text { (\%) }\end{array}$ & $\begin{array}{c}\text { Somebody else } \\
\text { (\%) }\end{array}$ \\
\hline Pro & 34 & 26 & 14 & 90 & 14 & 0 \\
\hline$T a$ & 43 & 20 & 29 & 95 & 45 & 0 \\
\hline
\end{tabular}


As we can see in Table 11, the acceptability of both NS and pronoun improves significantly - the difference between (15) and (16) for values $4+3$ is $p=0.0200$, and the fact that the NS is still marginal can be thus attributed to the MOLC, since the topic chain is headed by a silent A-Topic. Notice that a very significant variation also concerns the identification of the DP Zhangsan as the silent A-Topic of the matrix clause. ${ }^{18}$

The next section, dedicated to the analysis of sentences including adverbial clauses, will be preceded by a brief introduction, which is necessary to understand the following discussion.

\section{Central and peripheral adverbial clauses: A short overview}

In her recent, seminal investigation on adverbial clauses, Haegeman (2002, 2010, 2012) provided evidence that adverbial clauses are not a homogenous group and that at least two types must be distinguished, namely, central and peripheral adverbial clauses. The former modify the proposition expressed by the clause with which they are related, while the latter provide background propositions to be processed as the privileged discourse context for the proposition expressed in the associated clause. It is then argued that these two types of clauses differ in both external and internal syntax, and different explanations have been proposed to account for this.

Given this characterization, the data discussed in this section are intended to evaluate if and to what extent the acceptability and interpretation of pro(noun)s in Chinese support the necessity of such a distinction. Furthermore, whereas adverbial clauses are generally assumed to be merged in the split-TP area (cf., among others, Haegeman 2012), scholars of Chinese syntax like Paul (2015) and Wang (1995) have argued for a prototypical initial position. However,

18 A reviewer wonders whether the low score attested for (15) might be due to the fact that the two sentences are not logically relevant (i.e., there is no logical relation between the fact that 'Zhangsan took his son to the cinema' and that 'Pro/He is happy') and suggests to try a sentence like (i) given in the following, where s/he finds an overt pronoun to be acceptable:

(i) Zhangsan zhidao-le ziji de erzi kaoshang-le Sitanfu_/ta shifen kaixin.

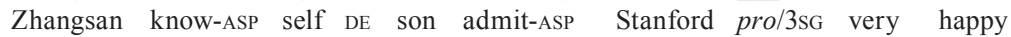
'Zhangsan learned that his own son was admitted to Stanford. Pro/He is very happy.'

However, after trying this sentence with informants, we found out that acceptability rates do not improve for either pro or $t a$. The reviewer's intuition seems to be led by interpretive factors since, in fact, the matrix subject Zhangsan is strongly preferred in the presence of $t a$ with sentence (i). In other words, ambiguity seems to be solved with respect to (15), but not acceptability, thus supporting the centrality of (overt) A-Topic chains. 
Wang (1995), Paul (2015), and Pan and Paul (2018) also show that in Chinese, an adverbial clause can appear in both initial (either merged in Spec,TopP or as an adjunct to TP) and final positions. However, based on syntactic constraints, Pan and Paul (2018) importantly conclude that neither position is derived from the other. For this reason, we decided to test the acceptability and interpretation of an NS in both positions, to check the interpretive effect (if any) of a supposed movement operation.

In particular, we have tested temporal and conditional adverbials for the central type and concessive adverbials as peripheral clauses. Indeed, it is generally agreed that temporal and conditional adverbial clauses resist root phenomena, a restriction that originates from their nature as relative clauses (for details, cf. Haegeman 2010, 2012) and thus implies that they cannot host an A-Topic in their $\mathrm{C}$-domain. On the other hand, peripheral adverbial clauses, like concessive clauses, are not derived by operator movement, since elements as "though" are sentential functions and not quantifiers; hence, they are compatible with root phenomena like argument fronting in English, as is shown in Quirk et al. (1985: 1378) in sentences like "His face not many admired, while his character still fewer felt they could praise."

\subsection{The interpretation of pro(noun)s in temporal adverbial clauses}

To provide an immediate comparison between the results obtained in pre- and postmatrix positions, in this and the following sections, the two relevant examples will be given one after the other, followed by a single table and relevant observations. Consider then the following:

(17) Gongzuo __ jieshu yihou, Zhangsan cai neng kan dianying. work finish after Zhangsan only can watch movie 'After finishing work, Zhangsan can watch a movie.'

(18) Zhangsan cai neng kan dianying, gongzuo _ _ jieshu yihou. Zhansgsan only can watch movie work finish after 'Zhangsan can watch a movie, only after finishing work.'

Table 12 Pre- and post-matrix temporal clause with an NS in the adverbial clause

\begin{tabular}{|l|c|c|c|c|c|}
\hline & \multicolumn{3}{|c|}{ Acceptability } & \multicolumn{2}{c|}{ Interpretation } \\
\hline & $\begin{array}{c}\text { Value 4 } \\
\text { (\%) }\end{array}$ & $\begin{array}{c}\text { Value 3 } \\
\text { (\%) }\end{array}$ & $\begin{array}{c}\text { Value 2 } \\
\text { (\%) }\end{array}$ & $\begin{array}{c}\text { Zhangsan } \\
\text { (\%) }\end{array}$ & $\begin{array}{c}\text { Somebody else } \\
\text { (\%) }\end{array}$ \\
\hline$(17)$ & 71 & 22 & 7 & 93 & 7 \\
\hline$(18)$ & 7 & 0 & 22 & 7 & 0 \\
\hline
\end{tabular}


This comparison provided in Table 12 clearly shows that an NS in a pre-matrix temporal clause like (17) is fully accepted, with a positive evaluation that only equals the one attested for NSs in the complement of a bridge verb (cf. Table 2), whereas an NS sitting in a post-matrix adverbial clause is totally refuted..$^{19,20}$ This result might seem surprising, since in both cases, the DP Zhangsan is the

19 Two SCL reviewers wonder why the DP gongzuo is assumed to be topicalized in (17). As a matter of fact, alternative analyses might be assumed for the adverbial clause as, for instance, an ergative analysis, according to which gongzuo would be part of a middle construction. This analysis has been proposed for similar structures by Cheng and Huang (1994) and is apparently supported by the fact that a sentence like (ia) given in the following is ungrammatical, apparently because nothing in the relative clause can be coindexed with its head. On the other hand, a sentence like (ib) is totally fine:

(ia) *Shoupa ku-shi-le de ren lai-le. handkerchief cry-wet-asp DE person come-asp

'The person such that the handkerchief was cried-wet came.'

(ib) Ku-shi-le shoupa de ren lai-le.

cry-wet-asp handkerchief DE person come-asp

'The person who cried and made the handkerchief wet came.'

Cheng and Huang (1994) argue that this asymmetry could not be explained if a sentence like (ia) is analyzed as a topic construction, since in this case, an agent-antecedent would be available.

After investigating with informants, however, we could find out that a sentence like (ii) given in the following - which parallels (ia) - is judged as grammatical. This shows that the adverbial clause in (17) cannot be considered as an ergative structure and, consequently, that gongzuo can be feasibly analyzed as a topic, with a pro in subject position:

(ii) $\left[_{\mathrm{TopP}}\right.$ Gongzuo $\left[_{\mathrm{TP}}\right.$ pro jieshu] de ren hui jia qu le. work pro finish DE person return home go ASP

'The person who finished work went back home.'

20 Another reviewer outlines a second possible problem for the topic analysis proposed for the DP gongzuo, related to the fact that an overt pronoun cannot be inserted in the position where an NS is assumed to sit in (17):

(i) *Gongzuo ta jieshu yihou, Zhangsan cai neng kan dianying. work 3SG finish after Zhangsan only can watch movie

'After he finishes working, Zhangsan can watch the movie.'

However, we reckon that the ungrammaticality of (i) should be attributed to the fact that in the adverbial clause, an infinitive form of the verb is realized (on the feasibility of assuming nonfinite forms in Chinese, cf. Landau 2015; Zhang 2016). This means that the NS in this case is a PRO (rather than a pro), and as such, it cannot be replaced by an overt subject. This hypothesis is supported by the fact that the pronoun $t a$ is acceptable if realized before gongzuo, as a topic (acceptability rate: $66 \%$ ), as is shown in the following:

(ii) Ta gongzuo jieshu yihou, Zhangsan cai neng kan dianying.

3SG work finish after Zhangsan only can watch movie

Lit.: 'He after finishing working, Zhangsan can watch the movie.'

Finally notice that $t a$ in (ii) cannot be analyzed as a possessive of gongzuo (meaning 'your work') since using a pronoun like wo yields ungrammatical effects (acceptability rate $0 \%$ ):

(iii) *Wo gongzuo jieshu yihou, Zhangsan cai neng kan dianying. 1sG work finish after Zhangsan only can watch movie

This contrast provides strong evidence that in this type of construction, an initial pronoun is a G-Topic and, as such, it must be connected to an A-Topic for interpretation. Hence, while in (ii) ta can have Zhangsan as an antecedent, wo in (iii) cannot be linked to any element 
matrix overt topic-subject. Indeed, sentence (18) could be expected to be preferred since the DP Zhangsan precedes the NS in surface structure.

This unexpected result, however, can be explained if we consider the acceptability of a sentence in which the post-matrix adverbial clause contains an overt subject, as is given in the following: cai neng kan dianying, Zhangsan gongzuo jieshu yihou. pro only can watch movie Zhangsan work finish after 'Pro can watch a movie, once Zhangsan has finished to work.'

Table 13 Matrix NS and post-matrix temporal clause

\begin{tabular}{|l|c|c|c|c|}
\hline \multicolumn{3}{|c|}{ Acceptability } & \multicolumn{2}{c|}{ Interpretation } \\
\hline $\begin{array}{l}\text { Value 4 } \\
(\%)\end{array}$ & $\begin{array}{c}\text { Value 3 } \\
(\%)\end{array}$ & $\begin{array}{c}\text { Value 2 } \\
(\%)\end{array}$ & $\begin{array}{c}\text { Zhangsan } \\
(\%)\end{array}$ & $\begin{array}{c}\text { Somebody else } \\
(\%)\end{array}$ \\
\hline 2 & 0 & 15 & 2 & 0 \\
\hline
\end{tabular}

As we can see in Table 13, this sentence is totally refuted by informants, showing that the unacceptability of (18) is independent of the presence of an NS. Given this scenario, the crucial point is therefore to understand (a) why a temporal clause is not accepted in post-matrix position and (b) why an NS is accepted in a pre-matrix temporal clause even if the topic-subject heading the chain follows it. We reckon that the solution to these questions lies in the combination between the derivation of temporal clauses and their discourse function.

As mentioned before, central adverbial clauses have been argued to originate from relative clauses, and in this respect, substantial cross-linguistic evidence is provided in Puglielli and Frascarelli (2011). Languages like Somali, for instance, show that adverbial clauses are headed by a generic NP such as "time," "way/ manner," and "turn/condition," and are characterized by operator properties. Specifically, temporal and conditional adverbial clauses are non-restrictive relative clauses, which can be introduced by a COMP-like element, as is shown in the following (AN.DET $=$ anaphoric article; $\mathrm{FM}=$ focus marker):

(20) a. [gabartii [oo markaas guriga galaysá]] baan arkay. girl.AN.DET COMP time.DEM house.DET enter. PROG FM.1SCL saw.1sG 'I saw the girl when (lit.: 'that [discourse-given] time') she was coming home.'

b. [haddii Cali uu yimaadó] waan la hadli lahaa. turn.AN.DET Cali SCL.3SGM come.SUB DECL.SCL.1SG with talk had 'If (lit.: '[given] the condition [that]') Cali came I would talk with him.'

(i.e., it can be neither the subject of the adverbial clause, since temporal clauses are non-finite, nor connected to the subject of the matrix clause). 
Following Rebuschi (2005), Puglielli and Frascarelli (2005) argue that nonrestrictive relative clauses are assertive sentences "conjoined" to their antecedent. According to this structural analysis, the antecedent is merged as an independent and fully referential DP, while the non-restrictive relative clause is a CP providing additional information about it (e.g., a property, a definite description, etc.; cf. Chierchia and McConnel-Ginet 1990; Del Gobbo 2003):

$$
\left[{ }_{\text {Conjp }}\left[\mathrm{DP}_{\mathrm{k}} \text {-head }\right]\left[_{\text {Conj' }^{\prime}} \mathrm{CONJ}^{\circ}\left[{ }_{\mathrm{CP} \text { NON-RESTR REL }}<\mathrm{DP}>{ }_{\mathrm{k}} / \operatorname{pron}_{\mathrm{k}}\left[\left[_{\mathrm{C}},\left[_{\mathrm{IP}} \ldots \mathrm{t}_{\mathrm{k}} \ldots\right]\right]\right]\right]\right]\right.
$$

Hence, the antecedent DP is not the head of an A'-chain but is merged in the Spec position of a ConjP projection having the relative $\mathrm{CP}$ as its complement. The DP head is therefore coindexed with either a silent copy or a relative pronoun (an "e-type" pronoun, cf. Heim 1990) sitting in the operator position of the nonrestrictive $\mathrm{CP}$.

In this line of analysis, it is feasible to surmise that central adverbial clauses in Chinese originate as in (21). ${ }^{21}$ However, given their discourse role as "frame-setters" (a major function in Chinese discourse grammar; cf. Chafe 1987; Lambrecht 1994; Krifka 2007; Paul 2015; Pan and Paul 2018), they move to a dedicated position in the C-domain (FrameP, as is proposed in Frascarelli 2017b):22

21 As a matter of fact, even though words like yihou in (17)-(19) are generally analyzed as postpositions, an analysis of central adverbials in terms of relative clauses is supported in Chinese by sentences like (i) given in the following:

(i) Wo qu Zhongguo de shihou...

1SG go China DE time

'When I went to China...'

The cross-categorical properties (and possibly the common origin) of pre- and post-positions and expressions of time/space are very common across languages (cf. Puglielli and Frascarelli 2011 for data and discussion). Nevertheless, different analyses have been proposed for relative clauses in Chinese in the literature, and no consensus can be found for a clear-cut distinction between restrictive and non-restrictive clauses. Taking the demonstrative as a watershed, Huang et al. (2009) propose that restrictive relatives precede it (ii), while non-restrictive clauses are located between the demonstrative and the head noun (as in [iii]):

(ii) $[$ Ta xihuan de] na (yi)-ge haizi]. 3SG like DE that one-CL child

'The child that he likes.'

(iii) $[\mathrm{Na}$ (yi)-ge [ta xihuan de $]$ haizi]. that one-CL 3SG like DE child

'The child, which he likes.'

However, Del Gobbo (2003) argues that the so-called non-restrictive relatives in Chinese cannot be considered on a par with appositives in English, since in some respects, they behave like English restrictive clauses (e.g., with elements modified by a quantifier like every). A detailed discussion is however beyond (and immaterial for) the purposes of the present analysis; interested readers are therefore referred to the cited works.

22 Interestingly, this type of dislocation has been defined by Chafe (1976) as "Chinese style" topicalization, whereas Lambrecht (1994) and Krifka (2007) propose these topics more generally as "scene-setting" topics and "frame-setting" topics, respectively. Frame-setters differ from 


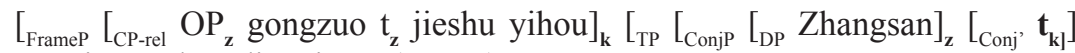
$\left[{ }_{T}\right.$, cai neng kan dianying] $](=[17])$

Given the derivation illustrated in (22), we can explain why an NS is fully accepted in this context: the topic-subject is coindexed with the operator of a relative clause originally merged in the complement position. In other words, the DP Zhangsan is a local and overt A-Topic for the relevant NS.

This analysis also provides an explanation for the ban against a post-matrix position of a central adverbial clause. Being a frame-setter, dislocation is "criterial" for interpretation (cf. Rizzi 2006). Hence, their merge position cannot be maintained in surface structure for information-structure requirements (similar to operations such as $w h$-movement in languages like English or Italian). Given this analysis, we are now in a position to provide an immediate explanation for the results obtained with sentences like (23), in which the NS is realized in a matrix clause that is preceded by the central adverbial clause:

(23) Zhangsan gongzuo jieshu yihou, /ta cai neng kan dianying. Zhangsan work finish after pro/3sg only can watch movie 'Once Zhangsan has finished work, pro can watch a movie.'

Table 14 Pre-matrix temporal clause preceded by the antecedent DP

\begin{tabular}{|l|c|c|c|c|c|}
\hline & \multicolumn{3}{|c|}{ Acceptability } & \multicolumn{2}{c|}{ Interpretation } \\
\hline & $\begin{array}{c}\text { Value 4 } \\
\text { (\%) }\end{array}$ & $\begin{array}{c}\text { Value 3 } \\
\text { (\%) }\end{array}$ & $\begin{array}{c}\text { Value 2 } \\
\text { (\%) }\end{array}$ & $\begin{array}{c}\text { Zhangsan } \\
\text { (\%) }\end{array}$ & $\begin{array}{c}\text { Somebody else } \\
\text { (\%) }\end{array}$ \\
\hline Pro & 40 & 33 & 18 & 65 & 14 \\
\hline$T a$ & 31 & 24 & 22 & 40 & 26 \\
\hline
\end{tabular}

Table 14 shows that acceptability rates increase significantly with respect to (18), even though values 3 and 4 are both below 50\%. Given the derivation illustrated in (22), a higher position of Zhangsan implies its movement from Spec,ConjP to a position that is higher that FramP. ${ }^{23}$ Since subjects are islands (cf. Lasnik and Saito 1992, among many others, for discussion), this movement triggers independent effects on acceptability judgments. ${ }^{24}$

A-Topics insofar as they do not represent entities creating "folders" under which information is stored: these elements have the semantic function of limiting the truth-conditional validity of the sentence it is associated with within some particular domain (especially regarding time and space; for discussion, cf. Frascarelli 2017b).

23 In this respect, it is important to underline that two alternative derivations have been proposed for Chinese topics in the literature (Badan \& Del Gobbo 2010; Huang et al. 2009): external merge in the C-domain and internal merge (i.e., movement) from a TP-internal position.

24 A reviewer objects that an explanation in terms of islands can be biased by the fact that it is possible to find acceptable examples in Mandarin that violate the subject condition (cf. Huang 


\subsection{Conditional adverbial clauses}

As in the case of temporal clauses, we start the analysis of conditional clauses with an immediate comparison between the pre- and the post-matrix position, followed by a single table and relevant observations:

(24) Ruguo __ _ta neng ba yu dou chi-wan, Sunli hui hen gaoxing. if $p r o / 3 \mathrm{sg}$ can BA fish all eat-finish Sunli can very happy 'If pro/she can finish all the fish, Sunli will be happy.'

(25) Sunli hui hen gaoxing, ruguo ___ta neng ba yu dou chi-wan. Sunli can very happy if $\overline{p r o} / 3 \mathrm{sg}$ can $\mathrm{BA}$ fish all eat-finish 'Sunli will be happy, if pro/she can finish all the fish.'

Table 15 Pre- and post-matrix conditional clauses with a pro(noun) in the adverbial clause

\begin{tabular}{|l|l|c|c|c|c|c|}
\hline & & \multicolumn{3}{|c|}{ Acceptability } & \multicolumn{2}{c|}{ Interpretation } \\
\hline \multirow{2}{*}{} & & $\begin{array}{c}\text { Value 4 } \\
\text { (\%) }\end{array}$ & $\begin{array}{c}\text { Value 3 } \\
\text { (\%) }\end{array}$ & $\begin{array}{c}\text { Value 2 } \\
\text { (\%) }\end{array}$ & $\begin{array}{c}\text { Sunli } \\
\text { (\%) }\end{array}$ & $\begin{array}{c}\text { Somebody else } \\
(\mathbf{\%})\end{array}$ \\
\hline \multirow{2}{*}{$(24)$} & Pro & 58 & 29 & 7 & 28 & 56 \\
\cline { 2 - 7 } & $T a$ & 62 & 29 & 4 & 11 & 87 \\
\hline \multirow{2}{*}{$(25)$} & Pro & 24 & 22 & 31 & 32 & 25 \\
\cline { 2 - 7 } & Ta & 36 & 27 & 29 & 44 & 33 \\
\hline
\end{tabular}

If we compare the results shown in Table 15 with those obtained with temporal clauses (cf. Table 12), we can immediately conclude that these two types of adverbial clauses cannot be treated on a par in Chinese. On the one hand, value 4 is much lower in the pre-matrix position, comparing (24) and (17), and on the other hand, the post-matrix position is possible (although marginal) for conditionals (with a significant difference with respect to temporal clauses: $p=0.0013)$.

Interpretive rates are also quite different, and this difference can help relevant understanding. As we can see, the selection of the intended antecedent (Sunli) is far from the 93\% scored by Zhangsan in (17), while an external (unmentioned) referent is preferred as an antecedent for pro in (24).

1984; Huang et al. 2009). We thank the reviewer for this comment. As a matter of fact, Chinese is not sensitive to all island types. However, Huang et al. (2009) show that Chinese is subject to the left branch condition (LBC) and the Spec,ConjP in a coordinate phrase is exactly a left branch position. Hence, the present proposal is sound and can be maintained. 
We reckon that this difference lies in the syntactic function of ruguo: its initial position shows that it cannot be considered a $\mathrm{C}^{\circ}$ head (like yihou 'after' in temporal clauses) but an operator, in line with the analysis discussed in Haegeman (2010, 2012) ${ }^{25}$ It is therefore feasible to propose that the operator movement of ruguo in the conditional relative clause creates intervention effects in the topic chain created by the topic-subject Sunli. Hence, after moving to Spec,FramP an alternative, silent A-Topic is preferred as a chain head.

As for the possibility of a post-matrix position, this shows that conditional clauses are not necessarily frame-setters but can also serve an "afterthought" function in the discourse, as discussed in Wang (1995). However, when the conditional clause sits in post-matrix position, an agree relation with a silent topic is biased by the MOLC (given the presence of a most local and overt antecedent).

The relevance of the MOLC is also supported by sentences like (26a), showing that, if the Topic-subject moves to a position that is higher than the prematrix conditional clause, the sentence under examination is rejected. ${ }^{26}$ Once again, a context, given in (26b), does not help acceptability (nor interpretation):

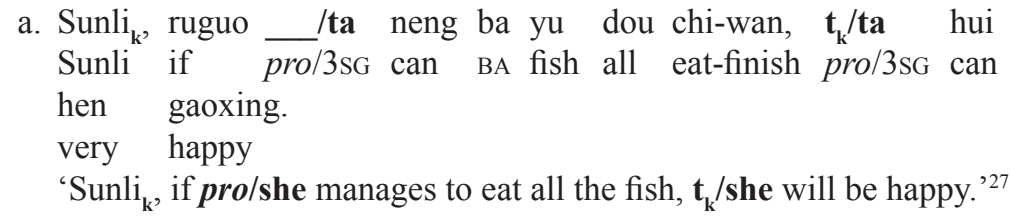

b. Sunli de nü'er zai xiuxi shijian chi de tai duo le. Sunli DE daughter in rest time eat DE too much PERF Sunli zhu le yu...

Sunli boil PERF fish

'During the break, Sunli's daugther ate too much. Sunli cooked fish ...'

Sunli $\mathbf{k}_{\mathbf{k}}$, ruguo __/ta neng ba yu dou chi-wan, $\mathbf{t}_{\mathbf{k}} / \mathbf{t a}$ hui hen gaoxing. 'Sunli $\mathbf{k}_{\mathbf{k}}$, if $\mathbf{p r o} / \mathbf{s h e}$ manages to eat all the fish, $\mathbf{t}_{\mathbf{k}} / \mathbf{s h e}$ will be happy.'

25 Specifically, drawing from Bhatt and Pancheva (2006), Haegeman (2012) suggests that conditional if clauses can be analyzed as free relatives of possible worlds, derived by the leftward movement of a world operator, associated with FinP in a cartographic approach.

26 Notice that in (26), acceptability is also worsened for the intervention effect determined by the NS in the conditional clause.

27 An anonymous reviewer suggests that sentences (26a,b) may become totally acceptable by changing the predicate gaoxing into cheng 'full'. Testing this new sentence, we found that acceptability rates effectively improve for the out-of-the-blue sentence; however, when the context is given, acceptability rates decrease, possibly because the use of cheng affects negatively the logical relation between matrix and adverbial clause. 
Table 16 Dislocated topic and pre-matrix conditional clause (with/out context)

\begin{tabular}{|c|c|c|c|c|c|c|c|c|}
\hline & & \multirow{2}{*}{\multicolumn{3}{|c|}{ Acceptability }} & \multicolumn{4}{|c|}{ Interpretation } \\
\hline & & & & & \multicolumn{2}{|c|}{$\begin{array}{c}\text { Conditional } \\
\text { clause }\end{array}$} & \multicolumn{2}{|c|}{ Matrix } \\
\hline & & $\begin{array}{c}\text { Value } 4 \\
(\%)\end{array}$ & $\begin{array}{c}\text { Value } 3 \\
(\%)\end{array}$ & $\begin{array}{c}\text { Value } 2 \\
(\%)\end{array}$ & $\begin{array}{c}\text { Sunli } \\
(\%)\end{array}$ & $\begin{array}{c}\text { Somebody } \\
\text { else } \\
(\%) \\
\end{array}$ & $\begin{array}{c}\text { Sunli } \\
(\%)\end{array}$ & $\begin{array}{c}\text { Somebody } \\
\text { else } \\
(\%) \\
\end{array}$ \\
\hline \multirow{2}{*}{$(26 a)$} & Pro & 9 & 22 & 36 & 28 & 3 & 28 & 3 \\
\hline & $T a$ & 7 & 4 & 13 & 11 & 0 & 6 & 5 \\
\hline \multirow[t]{2}{*}{ (26b) } & Pro & 18 & 7 & 27 & 22 & 7 & 22 & 7 \\
\hline & $T a$ & 22 & 12 & 24 & 16 & 2 & 5 & 8 \\
\hline
\end{tabular}

Let us now finally consider concessive clauses to evaluate if and to what extent differences emerge with a peripheral type of adverbial clause.

\subsection{Concessive adverbial clauses}

To provide an immediate follow-up to the analysis provided in the previous section, we will start the discussion of concessive clauses with the case examined for conditionals in (26a), that is to say, the dislocation of the topic-subject before the conditional clause:

(27) a. Sunli, suiran /ta tongguo le gaokao,

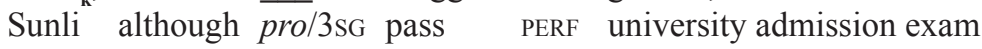
danshi $\mathbf{t}_{\mathbf{k}} / \mathbf{t a}$ haishi bu gaoxing. but $\mathrm{t}_{\mathrm{k}} / 3 \mathrm{sg}$ still NEG happy

'Sunli $i_{k}$, although pro $_{\mathbf{1}} / \mathbf{s h e}$ passed the university admission exam, $\mathbf{t}_{\mathbf{k}} / \mathbf{s h e}$ still not happy.'

Table 17 Dislocated topic and pre-matrix concessive clause (without context)

\begin{tabular}{|l|c|c|c|c|c|c|c|}
\hline \multirow{2}{*}{} & \multicolumn{3}{|c|}{ Acceptability } & \multicolumn{3}{c|}{ Interpretation } \\
\cline { 2 - 8 } & $\begin{array}{c}\text { Value 4 } \\
(\%)\end{array}$ & $\begin{array}{c}\text { Value 3 } \\
(\%)\end{array}$ & $\begin{array}{c}\text { Value 2 } \\
(\%)\end{array}$ & $\begin{array}{c}\text { Sunli } \\
(\%)\end{array}$ & $\begin{array}{c}\text { Somebody } \\
\text { else } \\
(\%)\end{array}$ & $\begin{array}{c}\text { Sunli } \\
(\%)\end{array}$ & $\begin{array}{c}\text { Somebody } \\
\text { else } \\
(\%)\end{array}$ \\
\hline Pro & 43 & 37 & 9 & 100 & 0 & 89 & 0 \\
\hline Ta & 28 & 11 & 17 & 86 & 14 & 100 & 14 \\
\hline
\end{tabular}

As we can see in Table 17, acceptability judgments are significantly different from those illustrated in Table 16, while they are very similar to those reported in 
Table 14 for temporal clauses. As for interpretation, Sunli is definitely preferred as the head of the relevant topic chain. This is clear evidence that no intervention effect is at stake in this sentence and, consequently, that suiran 'although' is not an operator.

Given this scenario, it is interesting to notice that, if a context is given inducing an alternative, silent A-Topic for the NS in the concessive clause, as in (27b), the relevant sentence is rejected. This is additional evidence that topic chains can be created with silent topics in a radical language like Chinese and also that overt minimal links have a crucial role for acceptability. Hence, the topic chain illustrated in (27b) suffers from the MOLC effect induced by Sunli, despite the context:

b. Sunli xiang rang ta de nü'er zai Nankai Daxue xuexi. Sunli wish to let 3SG DE daughter in Nankai University study

Zuotian Sunli de nü'er tongguo le Tianjin Daxue yesterday Sunli DE daughter pass PERF Tianjin University yixue xi de gaokao.

medicine department DE university admission exam

'Sunli would like her daughter to study at Nankai University. Sunli's daughter yesterday passed the test to enter the Medicine Department of Tianjin University.'

Sunli ${ }_{k}$, suiran pro/ta tongguo le gaokao, danshi $\mathbf{t}_{\mathbf{k}} / \mathbf{t a}$ haishi bu gaoxing. 'Sunli ${ }_{\mathbf{k}}$, although pro $_{\mathbf{1}} / \mathbf{s h e}$ passed the university admission exam, $\mathbf{t}_{\mathbf{k}} / \mathbf{s h e}$ is still not happy.'

Table 18 Dislocated topic and pre-matrix concessive clause (with context)

\begin{tabular}{|c|c|c|c|c|c|c|c|}
\hline & \multirow{2}{*}{\multicolumn{3}{|c|}{ Acceptability }} & \multicolumn{4}{|c|}{ Interpretation } \\
\hline & & & & \multicolumn{2}{|c|}{ Concessive clause } & \multicolumn{2}{|r|}{ Matrix } \\
\hline & $\begin{array}{c}\text { Value } 4 \\
(\%)\end{array}$ & $\begin{array}{c}\text { Values } 3 \\
(\%)\end{array}$ & $\begin{array}{c}\text { Value } 2 \\
(\%)\end{array}$ & $\begin{array}{c}\text { Sunli } \\
(\%)\end{array}$ & $\begin{array}{c}\text { S's daughter } \\
(\%)\end{array}$ & $\begin{array}{c}\text { Sunli } \\
(\%)\end{array}$ & $\begin{array}{c}\text { S's daughter } \\
(\%)\end{array}$ \\
\hline Pro & 20 & 14 & 14 & 58 & 42 & 83 & 25 \\
\hline$T a$ & 37 & 17 & 14 & 0 & 100 & 58 & 68 \\
\hline
\end{tabular}

To conclude this section, let us consider sentences in which the concessive clause is realized in a post-matrix position.

(28) Sunli hai bu gaoxing, suiran /ta tongue le gaokao.

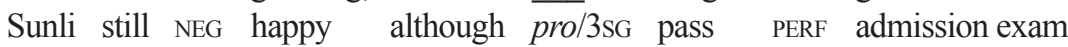
'Sunli is still not happy, although pro passed the university admission exam.' 
Table 19 Pro(noun) in concessive clause in post-matrix position

\begin{tabular}{|l|c|c|c|c|c|}
\hline & \multicolumn{3}{|c|}{ Acceptability } & \multicolumn{2}{c|}{$\begin{array}{c}\text { Interpretation } \\
\text { (\% for values 3+4) }\end{array}$} \\
\hline & $\begin{array}{c}\text { Value 4 } \\
\text { (\%) }\end{array}$ & $\begin{array}{c}\text { Value 3 } \\
\text { (\%) }\end{array}$ & $\begin{array}{c}\text { Value 2 } \\
(\text { \%) }\end{array}$ & $\begin{array}{c}\text { Sunli } \\
\text { (\%) }\end{array}$ & $\begin{array}{c}\text { Somebody else } \\
\text { (\%) }\end{array}$ \\
\hline Pro & 40 & 23 & 20 & 95 & 9 \\
\hline$T a$ & 37 & 31 & 14 & 87 & 17 \\
\hline
\end{tabular}

Table 19 shows that a post-matrix position is possible for the concessive clause, and these findings bring to light a final conclusion, namely, that concessive clauses are not relative clauses. This means that concessive clauses are not merged in the complement position of a ConjP projection but as independent CPs, either in Spec,FrameP or in the Spec of a projection composing the split-TP zone (cf. Cinque 1999). This also implies that concessives are not derived through operator movement. However, since the initial position of suiran excludes a COMP analysis, we surmise that this element can be considered as an adverbial-like element, merged in the split-TP area (possibly MoodP). We leave this issue for future research.

\section{Conclusions}

In the light of the data examined, it can be argued that the interpretation of pro relies on the topic criterion (5) and the creation of topic chains, cf. (6), also in a radical pro-drop language like Chinese, thereby supporting the theory that the acceptability and interpretation of NSs crucially depend on an IS strategy.

As a matter of fact, data have shown that a context analysis cannot be maintained in Chinese. Indeed, when the context proposes a topic that is not structurally realized as such in the sentence, ambiguity is created - an output that is utterly rejected by Chinese informants. On the other hand, Chinese has shown specificities with respect to consistent pro-drop languages, which must be dealt with and "integrated" in the theory on the NS parameter for a comprehensive account.

In particular, the most important difference rests on the use and acceptability of silent topics: even though results show that a chain can be started by a silent topic (consistent with the topic criterion), the "ideal antecedent" for an NS in radical Chinese is an overt, local A-Topic, merged in a root clause. This locality requirement has been traced back to a general syntactic condition in which interface (i.e., interpretive) visibility has been integrated. This is the MOLC, which has been recently proposed in Frascarelli and Jiménez-Fernández (in press) to account for partial pro-drop languages, thus showing the existence of an interesting parallel between partial and radical pro-drop languages, to be further investigated in future research. 
As for embedded contexts, silent topics that are different from the local topicsubject are possible (though marginal) only if they are embedded under bridge verbs. NSs in double-embedded contexts are refuted by informants.

The present analysis has also contributed to outline the structural differences existing between adverbials in Chinese, supporting a distinction between central and peripheral adverbial clauses. In particular, while temporal and conditional clauses show the properties of non-restrictive relative clauses conjoined with their antecedent, this is not the case for concessive clauses, which are not derived through operator movement but merged as subordinate clauses either in the C-domain or in the high split-TP zone. Differences between temporal and conditional clauses can be attributed to the presence of an overt operator, creating intervention effects. Finally, the pre-matrix position of adverbial clauses has been explained in the light of their discourse role as frame-setters.

\section{Acknowledgments}

We wish to thank the audience of the 44th Incontro di Grammatica Generativa (University of Roma Tre), where a previous version of this paper has been presented, for valuable feedback and suggestions. In particular, we acknowledge Waltraud (Walli) Paul and Victor Pan for their comments and precious help (also in contacting informants). Finally, we thank two SCL reviewers for their comments and precious suggestions, which greatly helped us improving this work.

\section{References}

Badan, Linda \& Francesca Del Gobbo. 2010. On the syntax of topic and focus in Chinese. In Paola Benincà \& Nicola Munaro (eds.), Mapping the left periphery: The cartography of syntactic structures, vol. 5, 63-90. Oxford: Oxford University Press.

Bhatt, Rajesh \& Roumyana Pancheva. 2006. Conditionals. In Martin Everaert \& Henk van Riemsdijk (eds.), The Blackwell companion to syntax, vol. 1, 638-687. Boston \& Oxford: Blackwell.

Bianchi, Valentina \& Mara Frascarelli. 2010. Is topic a root phenomenon? Iberia: An International Journal of Theoretical Linguistics 2(1). 43-88.

Biberauer, Theresa, Anders Holmberg, Ian Roberts \& Michelle Sheenan. 2010. Parametric variation: Null subject in minimalist theory. Cambridge: Cambridge University Press.

Bonvino, Elisabetta. 2006. Le sujet postverbal en italien parlé: Syntaxe, zones et intonation (Biblioteque des Faits de Langue). Paris: Ophrys.

Chafe, Wallace. 1976. Givenness, contrastiveness, definiteness, subjects, topics and point of view. In Charles N. Li (ed.), Subject and topic, 25-55. New York: Academic Press.

Chafe, Wallace. 1987. Cognitive constraints and information flow. In Russel S. Tomlin (ed.), Coherence and grounding in discourse: Outcome of a symposium, 21-51. Amsterdam \& Philadelphia: John Benjamins. 
Chierchia, Gennaro \& Sally McConnell-Ginet. 1990. Meaning and grammar. Cambridge MA: MIT Press.

Cinque, Guglielmo. 1999. Adverbs and functional heads: A cross-linguistic perspective. Oxford: Oxford University Press.

D’Alessandro, Roberta. 2015. Null subject. In Antonio Fábregas, Jaume Mateu \& Mike Putnam (eds.), Contemporary linguistic parameters, 201-226. London, Oxford, New York: Bloomsbury Academic.

Del Gobbo, Francesca. 2003. Appositives at the interface. Irvine, CA: University of California Irvine dissertation.

Ding, Hongdi. 2009. Hanyu huati jiegou de guangyi zuo xiang hebing moshi yanjiu [A generalized leftward merger interpretation of Chinese topic structures]. Journal of Guangdong University of Foreign Studies 20(2). 58-63.

Emonds, Joseph. 2004. Unspecified categories as in the key to root constructions. In David Adger, Cécile de Cat \& Georges Tsoulas (eds.), Peripheries: Syntactic edges and their effects, 75-120. Dordrecht: Kluwer.

Erteschik-Shir, Nomi. 2006. Bridge Phenomena. In Martin Everaert \& Henk van Riemsdijk (eds.), The Blackwell companion of syntax, vol. 1, 284-294. Boston \& Oxford: Blackwell.

Frascarelli, Mara. 2007. Subjects, topics and the interpretation of referential pro: An interface approach to the linking of (null) pronouns. Natural Language and Linguistic Theory 25(4). 691-734.

Frascarelli, Mara. 2017a. Romance pro-drop languages at the interfaces: A comparative analysis. Paper presented at the 31st Going Romance Symposyum, University of Bucharest, 7-9 December.

Frascarelli, Mara. 2017b. Dislocations and Framings. In Elisabeth Stark \& Andreas Dufter (eds.), Manual of Romance morphosyntax and syntax, 472-501. Berlin: Mouton de Gruyter.

Frascarelli, Mara. 2018. The interpretation of pro in consistent and partial NS languages: A comparative interface analysis. In Federica Cognola \& Jan Casalicchio (eds.), Null-subjects in generative grammar: A synchronic and diachronic perspective, 211-239. Oxford \& New York: Oxford University Press.

Frascarelli, Mara \& Roland Hinterhölzl. 2007. Types of topics in German and Italian. In Susanne Winkler \& Kerstin Schwabe (eds.), On information structure, meaning and form, 87-116. Amsterdam \& Philadelphia: John Benjamins.

Frascarelli, Mara \& Ángel L. Jiménez-Fernández. In press. Understanding partiality in pro-drop languages: An information-structure approach. Syntax [Special issue on information structure].

Fu, Yiting. 2011. A syntactic contrast of English and Chinese-Subject-prominent vs. topic-prominent. Overseas English 2. 394-395.

Gelderen, Elly van. 2013, Null subjects in old English. Linguistic Inquiry 44. 271-285. Haegeman, Liliane. 2002. Anchoring to speaker, adverbial clauses and the structure of CP. Georgetown University Working Papers in Theoretical Linguistics 2. $117-180$. 
Haegeman, Liliane. 2010. The internal syntax of adverbial clauses. Lingua 120. $628-648$.

Haegeman, Liliane. 2012. Adverbial clauses, main clause phenomena, and the composition of the left periphery. Oxford: Oxford University Press.

Heim, Irene. 1982. The semantics of definite and indefinite noun phrases. Amherst, MA: University of Massachusetts dissertation.

Heim, Irene. 1990. E-type pronouns and donkey anaphora. Linguistics and Philosophy 13. 137-177.

Heycock, Caroline. 2006. Embedded Root Phenomena. In Martin Everaert \& Henk van Riemsdijk (eds.), The Blackwell companion to syntax, vol. 2, 174-209. Oxford: Blackwell.

Huang, C.-T. James. 1984. On the distribution and reference of empty pronouns. Linguistic Inquiry 15. 531-574.

Huang, C. T. James. 1989. Pro-drop in Chinese: A generalized control theory. In Osvaldo Jaeggli \& Ken Safir (eds.), The null subject parameter (Studies in Natural Language and Linguistic Theory, vol. 15), 185-214. Dordrecht: Springer Netherlands.

Huang, C. T. James, Y. H. Audrey Li \& Yafei Li. 2009. The syntax of Chinese. New York: Cambridge University Press.

Jiménez-Fernández, Ángel L. 2016. When discourse met null subjects. Borealis: An International Journal of Hispanic Linguistics 5(2). 173-189.

Jiménez-Fernández, Ángel L. \& Shigeru Miyagawa. 2014. A feature-inheritance approach to root phenomena and parametric variation. Lingua 145. 275-302.

Kibort, Anna \& Greville G. Corbett (eds.) 2010. Features: Perspectives on a key notion in linguistics. Oxford: Oxford University Press.

Krifka, Manfred. 2001. Quantifying into question acts. Natural Language Semantics 9. $1-40$.

Krifka, Manfred. 2007. Basic notions of information structure. In Caroline Féry, Gisbert Fanselow \& Manfred Krifka (eds.), Interdisciplinary studies on information structure 6. 13-55. Potsdam: Universitätsverlag.

Kuroda, Sige-Yuki. 1979 [1965]. Generative grammatical studies in the Japanese language. Cambridge, MA: MIT dissertation. Reprint, New York: Garland Press.

Lambrecht, Knud. 1994. Information structure and sentence form: Topic, focus and the ental representation of discourse referents. Cambridge: Cambridge University Press.

Landau, Idan. 2015. A two-tiered theory of control. Cambridge, MA: MIT Press.

LaPolla, Randy John. 2009. Chinese as a topic-comment (Not topic-prominent and not SVO) language. In Janet Xing (ed.), Studies of Chinese linguistics: Functional approaches, 9-22. Hong Kong: Hong Kong University Press.

Lasnik, Howard \& Mamoru Saito. 1992. Move $\alpha$ : Conditions on its application and output. Cambridge: MIT Press.

Manzini, Maria Rita. 1992. Locality: A theory and some of its empirical consequences. Cambridge, MA: MIT Press. 
Miyagawa, Shigeru \& Mamoru Saito. 2008. The Oxford handbook of Japanese linguistics. New York: Oxford University Press.

Neeleman, Ad \& Kriszta Szendrői. 2007. Radical pro-drop and the morphology of pronouns. Linguistic Inquiry 38. 671-714.

Neeleman, Ad, \& Kriszta Szendröi. 2008. Case morphology and radical pro-drop. In Biberauer Theresa (ed.), The limits of syntactic variation, 331-348. Amsterdam \& Philadelphia: John Benjamins.

Pan, Victor Junnan \& Waltraud Paul. 2018. The syntax of complex sentences in Mandarin Chinese: A comprehensive overview and analyses. In Victor Junnan Pan \& Waltraud Paul (eds.). The syntax of complex sentences in Chinese [Special issue]. Linguistic Analysis 42. 63-161.

Paul, Waltraud. 2015. New perspective on Chinese syntax. Berlin: Mouton de Gruyter.

Puglielli, Annarita \& Mara Frascarelli. 2005. A comparative analysis of restrictive and appositive relative clauses in Cushitic languages. In Brugè, Laura, Giuliana Giusti, Nicola Munaro, Walter Schweikert \& Giuseppina Turano (eds.), Contribution to the Incontro di Grammatica Generativa XXX, 279-303. Venezia: Cafoscarina.

Puglielli, Annarita \& Mara Frascarelli. 2009. Position, function and interpretation of topics in Somali. In Lunella Mereu (ed.), Information structure and its interfaces, 325-348. Berlin: Mouton de Gruyter.

Puglielli, Annarita \& Mara Frascarelli. 2011. Linguistic analysis: From data to theory. Berlin: Mouton de Gruyter.

Quirk, Randolph, Sidney Greenbaum, Geoffrey Leech \& Jan Svartvik. 1985. A comprehensive grammar of the English language. London: Longman.

Rebuschi, Georges. 2005. Generalizing the antisymmetric analysis of coordination to nominal modification. Lingua 115(4). 445-459.

Reinhart, Tania. 1982. Pragmatics and linguistics: An analysis of sentence topics. Philosophica 27. 53-94.

Rizzi, Luigi. 1990. Relativized minimality. Cambridge, MA: MIT Press.

Rizzi, Luigi. 1997. The fine structure of the left periphery. In Liliane Haegeman (ed.), Elements of grammar: Handbook in generative syntax, 281-337. Dordrecht: Kluwer.

Rizzi, Luigi. 2006. On the form of chains: Criterial positions and ECP effects. In Lisa Lai-Shen Cheng \& Norbert Corver (eds.), Wh-movement: Moving on, 97-133. Cambridge, MA: MIT Press.

Saito, Mamoru. 2007. Notes on East Asian argument ellipsis. Unpublished manuscript: Nanzan University and University of Connecticut.

Shi, Dingxu. 1998. Hanyu zhutiju de texing [The nature of Chinese topics]. Modern Foreign Languages 2. 40-57.

Shi, Dingxu. 2000. Topic and topic-comment construction in Mandarin Chinese. Language 76(2). 383-408.

Sigurdsson, Halldor. 2011. Conditions on argument drop. Linguistic Inquiry 42. 267-304. 
Song, Xiuping. 2009. Kong zhuyu (pro) zai ying han zhong de butong canshu shezhi [The licensing mechanism of English and Chinese pro]. Journal of Shanghai Normal University (Philosophy and Social Sciences Edition) 38(3). 128-132.

Sun, Kun. 2015. Hanyu huati lian fanchou, jiegou yu pianzhang gongneng [The category, structure and textual function of topic chains in Chinese discourse]. Language Teaching and Linguistic Studies 5. 72-82.

Tomioka, Satoshi. 2003. The semantics of Japanese null pronouns and its cross linguistic implications. In Kerstin Schwabe \& Susanne Winkle (eds.), The interfaces: Deriving and interpreting omitted structures, 321-339. Amsterdam \& Philadelphia: John Benjamins.

Villata, Sandra, Luigi Rizzi \& Julie Franck. 2016. Intervention effects and relativized minimality: New experimental evidence from graded judgments. Lingua 179. 76-96.

Wang, Yufang. 1995. A corpus-based study of adverbial clauses in Mandarin Chinese conversations: A preliminary analysis. In Benjamin K. T'sou \& Tom B. Y. Lai (eds.), Proceedings of the 10th Pacific Asia Conference on Language, Information and Computation. Hong Kong: City University of Hong Kong.

$\mathrm{Xu}$, Min. 2005. Kong zhuyu canshu he hanyu de wuzhuju [Null subject parameter and null subject in Chinese]. Journal of Southern Yangtze University (Humanities and Social Sciences Edition) 3. 92-94.

Yuan, Suwen. 2014. Cong kong yulei kan hanyu kongwei zhuyu [The analysis of Chinese null subjects based on empty categories]. Journal of Heilongjiang College of Education 33(7). 122-123.

Zhang, Niina Ning. 2016. Identifying Chinese dependent clauses in the forms of subjects. Journal of East Asian Linguist 25(3). 275-311.

Zheng, Chao. 2001. Kuochong de toushe yuanze yu Zhongguoren de zhuyu qianyishi [EPP and the sense of covert subject of native Chinese speakers]. Journal of PLA University of Foreign Languages, 24(3). 24-26.

\section{Appendix}

\section{NS embedded under a bridge verb (Paragraph 3.1)}

\subsection{First test}

(1a) 張三說要去接他妻子。 Zhangsan said _ has to go and pick up his wife.

(1b) 在會議期間宏亮突然站起來跑了出去：

During the meeting, Hongliang stood up abruptly and ran out (of the room). 張三說要去接他妻子。

Zhangsan said _ has to go and pick up his wife.

(2a) 張三說他要去接他妻子。

Zhangsan said he has to go and pick up his wife. 
(2b) 在會議期間宏亮突然站起來跑了出去：

During the meeting, Hongliang stood up abruptly and ran out (of the room). 張三說他要去接他妻子。

Zhangsan said he has to go and pick up his wife.

(3a) 張三說宏亮以爲應該買一輛車。

Zhangsan said that Hongliang thinks that should buy a car.

(3b) 張三的舊汽車突然壞了。宏亮是一個汽車維修員。檢查車以前宏亮告 訴張三可能是汽車引擎壤了, 如果是這樣的話, 維修車比買一輛新車 會更貴。最終宏亮找到了汽車出毛病的原因, 是因爲油表壞了。油表 出了故障使得張三不知道汽車已經沒油了, 所以車就突然停了下來：

Zhangsan's old car suddenly stopped. Hongliang is a mechanic. Before checking the car, Hongliang told Zhangsan that the engine might have broken; for this reason, fixing the car could be more expensive than buying a new one. Eventually, Hongliang found out that the car stopped because the petrol gage was broken and Zhangsan did not know that he ran out of gasoline:

張三說宏亮以爲應該買一輛車。

Zhangsan said that Hongliang thinks that should buy a car.

（3c）一天早上宏亮在車庫裡找不到自己的車。他認爲汽車被偷了。他感到 很著急因爲他沒有錢買一輛新車。最終, 他想起來昨天他把車借給了 自己的女兒：

One morning Hongliang couldn't find his car in his garage. He thought that it was stolen and got worried because he didn't have enough money to buy a new one. Eventually, he remembered that the previous day he lent the car to his daughter:

張三說宏亮以爲應該買一輛車。

Zhangsan said that Hongliang thinks that _ should buy a car.

(4a) 張三說宏亮以爲他應該買一輛車。

Zhangsan said that Hongliang thinks that he should buy a car.

(4b) 張三的舊汽車突然壞了。宏亮是一個汽車維修員。檢查車以前宏亮告 訴張三可能是汽車引擎壞了, 如果是這樣的話, 維修車比買一輛新車 會更貴。最終宏亮找到了汽車出毛病的原因, 是因爲油表壞了。油表 出了故障使得張三不知道汽車已經沒油了, 所以車就突然停了下來：

Zhangsan's old car suddenly stopped. Hongliang is a mechanic. Before checking the car, Hongliang told Zhangsan that the engine might have broken; for this reason, fixing the car could be more expensive than buying a new one. Eventually, Hongliang found out that the car stopped because the petrol gage was broken and Zhangsan did not know that he ran out of gasoline:

張三說宏亮以爲他應該買一輛車。

Zhangsan said that Hongliang thinks that he should buy a car. 
（4c）一天早上宏亮在車庫裡找不到自己的車。他認爲汽車被偷了。他感到 很著急因爲他沒有錢買一輛新車。最終, 他想起來昨天他把車借給了 自己的女兒：

One morning Hongliang couldn't find his car in his garage. He thought that it was stolen and got worried because he didn't have enough money to buy a new one. Eventually, he remembered that the previous day he lent the car to his daughter:

張三說宏亮以爲他應該買一輛車。

Zhangsan said that Hongliang thinks that he should buy a car.

(5a) 張三說宏亮認爲應該買一輛車。

Zhangsan said that Hongliang thinks that _ should buy a car.

(5b) 張三的舊汽車突然壤了。宏亮是一個維修員。檢查車以後, 宏亮發現 了維修車比買一輛新車更貴：

Zhangsan's old car suddenly stopped. Hongliang is a mechanic. After checking the car, Hongliang found out that fixing the car would be more expensive than buying a new one:

張三說宏亮認爲應該買一輛車。

Zhangsan said that Hongliang thinks that _ should buy a car.

(5c) 宏亮找到了新的工作。他現在比以前賺的多。一年以後他設法省下很 多錢。現在宏亮考慮把他的自行車換成一輛更加舒服的車輛：

Hongliang found a new job, and he's earning more money than before. After one year, he managed to save a lot of money. Hongliang is now considering changing his old bicycle with a more comfortable vehicle:

張三說宏亮認爲應該買一輛車。

Zhangsan said that Hongliang thinks that should buy a car.

(6a) 張三說宏亮認爲他應該買一輛車。

Zhangsan said that Hongliang thinks that he should buy a car.

(6b) 張三的舊汽車突然壞了。宏亮是一個維修員。檢查車以後, 宏亮發現 了維修車比買一輛新車更貴：

Zhangsan's old car suddenly stopped. Hongliang is a mechanic. After checking the car, Hongliang found out that fixing the car would be more expensive than buying a new one:

張三說宏亮認爲他應該買一輛車。

Zhangsan said that Hongliang thinks that he should buy a car.

（6c）宏亮找到了新的工作。他現在比以前賺的多。一年以後他設法省下很 多錢。現在宏亮考慮把他的自行車換成一輛更加舒服的車輛：

Hongliang found a new job, and he's earning more money than before. After one year, he managed to save a lot of money. Hongliang is now considering changing his old bicycle with a more comfortable vehicle:

張三說宏亮認爲他應該買一輛車。

Zhangsan said that Hongliang thinks that he should buy a car. 


\subsection{Second test (after reviewing)}

(7a) 張三覺得要去接他妻子。 Zhangsan thinks has to go and pick up his wife.

(7b) 在會議期間宏亮突然站起來跑了出去：

During the meeting, Hongliang stood up abruptly and ran out (of the room). 張三覺得要去接他妻子。 Zhangsan thinks _ has to go and pick up his wife.

(8a) 張三覺得他要去接他妻子。 Zhangsan thinks he has to go and pick up his wife.

(8b) 在會議期間宏亮突然站起來跑了出去：

During the meeting, Hongliang stood up abruptly and ran out (of the room). 張三覺得他要去接他妻子。

Zhangsan thinks he has to go and pick up his wife.

(9a) 張三覺得宏亮以爲應該買一輛車。 Zhangsan thinks Hongliang thinks should buy a new car.

(9b) 張三的舊汽車突然壞了。宏亮是一個汽車維修員。檢查車以前宏亮告 訴張三可能是汽車引擎壞了, 如果是這樣的話, 維修車比買一輛新車 會更貴。最終宏亮找到了汽車出毛病的原因, 是因爲油表壞了。油表 出了故障使得張三不知道汽車已經沒油了, 所以車就突然停了下來：

Zhangsan's old car suddenly stopped. Hongliang is a mechanic. Before checking the car, Hongliang told Zhangsan that the engine might have broken; for this reason, fixing the car could be more expensive than buying a new one. Eventually, Hongliang found out that the car stopped because the petrol gauge was broken and Zhangsan did not know that he ran out of gasoline:

張三覺得宏亮以爲應該買一輛車。

Zhangsan thinks Hongliang thinks _ should buy a new car.

（9c）一天早上宏亮在車庫裡找不到自己的車。他認爲汽車被偷了。他感到 很著急因爲他沒有錢買一輛新車。最終, 他想起來昨天他把車借給了 自己的女兒：

One morning Hongliang couldn't find his car in his garage. He thought that it was stolen and got worried because he didn't have enough money to buy a new one. Eventually, he remembered that the previous day he lent the car to his daughter:

張三覺得宏亮以爲應該買一輛車。

Zhangsan thinks Hongliang thinks _ should buy a new car.

(10a) 張三覺得宏亮以爲他應該買一輛車。

Zhangsan thinks Hongliang thinks he should buy a new car. 
(10b) 張三的舊汽車突然壞了。宏亮是一個汽車維修員。檢查車以前宏亮告 訴張三可能是汽車引擎壤了, 如果是這樣的話, 維修車比買一輛新車 會更貴。最終宏亮找到了汽車出毛病的原因, 是因爲油表壞了。油表 出了故障使得張三不知道汽車已經沒油了, 所以車就突然停了下來：

Zhangsan's old car suddenly stopped. Hongliang is a mechanic. Before checking the car, Hongliang told Zhangsan that the engine might have broken; for this reason, fixing the car could be more expensive than buying a new one. Eventually, Hongliang found out that the car stopped because the petrol gage was broken and Zhangsan did not know that he ran out of gasoline:

張三覺得宏亮以爲他應該買一輛車。

Zhangsan thinks Hongliang thinks he should buy a new car.

(10c) 一天早上宏亮在車庫裡找不到自己的車。他認爲汽車被偷了。他感到 很著急因爲他沒有錢買一輛新車。最終, 他想起來昨天他把車借給了 自己的女兒：

One morning, Hongliang couldn't find his car in his garage. He thought that it was stolen and got worried because he didn't have enough money to buy a new one. Eventually, he remembered that the previous day he lent the car to his daughter:

張三覺得宏亮以爲他應該買一輛車。

Zhangsan thinks Hongliang thinks he should buy a new car.

(11a) 張三覺得宏亮認爲要應該一輛車。

Zhangsan thinks Hongliang thinks _ should buy a new car.

(11b) 張三的舊汽車突然壞了。宏亮是一個維修員。檢查車以後, 宏亮發現 了維修車比買一輛新車更貴 :

Zhangsan's old car suddenly stopped. Hongliang is a mechanic. After checking the car, Hongliang found out that fixing the car would be more expensive than buying a new one:

張三覺得宏亮認爲應該買一輛車。

Zhangsan thinks Hongliang thinks _ should buy a new car.

(11c) 宏亮找到了新的工作。他現在比以前賺的多。一年以後他設法省下很 多錢。現在宏亮考慮把他的自行車換成一輛更加舒服的車輛：

Hongliang found a new job and he's earning more money than before. After one year he managed to save a lot of money. Hongliang is now considering changing his old bicycle with a more comfortable vehicle:

張三覺得宏亮認爲應該買一輛車。

Zhangsan thinks Hongliang thinks _ should buy a new car.

(12a) 張三覺得宏亮認爲他應該買一輛車。

Zhangsan thinks Hongliang thinks he should buy a new car. 
(12b) 張三的舊汽車突然壞了。宏亮是一個維修員。檢查車以後, 宏亮發現 了維修車比買一輛新車更貴 :

Zhangsan's old car suddenly stopped. Hongliang is a mechanic. After checking the car, Hongliang found out that fixing the car would be more expensive than buying a new one:

張三覺得宏亮認爲他應該買一輛車。

Zhangsan thinks Hongliang thinks he should buy a new car.

(12c) 宏亮找到了新的工作。他現在比以前賺的多。一年以後他設法省下很 多錢。現在宏亮考慮把他的自行車換成一輛更加舒服的車輛：

Hongliang found a new job and he's earning more money than before. After one year he managed to save a lot of money. Hongliang is now considering changing his old bicycle with a more comfortable vehicle:

張三覺得宏亮認爲他應該買一輛車。

Zhangsan thinks Hongliang thinks he should buy a new car.

\section{NS embedded under a factive verb (Paragraph 3.2)}

(13a) 張三很抱歉不能給她錢。

Zhangsan is very sorry _ can't give money to her.

(13b) 宏亮告訴張三他最近有困難, 他失業了而且他女兒想出國學習 :

Hongliang said to Zhangsan that he had been having a very difficult period: he lost his job and his daughter would like to go abroad for her studies: 張三很抱歉不能給她錢。

Zhangsan is very sorry _ can't give money to her.

(14a) 張三很抱歉他不能給她錢。

Zhangsan is very sorry he can't give money to her.

(14b) 宏亮告訴張三他最近有困難, 他失業了而且他女兒想出國學習 :

Hongliang said to Zhangsan that he had been having a very difficult period: he lost his job and his daughter would like to go abroad for her studies: 張三很抱歉他不能給她錢。

Zhangsan is very sorry he can't give money to her.

(15a) 張三很遺憾不能給孫儷錢。

Zhangsan regrets that _ can't give money to Sunli.

(15b) 宏亮告訴張三他最近有困難, 他失業了而且他女兒孫麗想出國學習 :

Hongliang said to Zhangsan that he had been having a very difficult period: he lost his job and his daughter Sunli would like to go abroad for her studies: 張三很遺憾不能給孫裉錢。

Zhangsan regrets that _ can't give money to Sunli.

(16a) 張三很遺憾他不能給孫儷錢。

Zhangsan regrets that he can't give money to Sunli. 
(16b) 宏亮告訴張三他最近有困難, 他失業了而且他女兒孫儷想出國學 習：

Hongliang said to Zhangsan that he had been having a very difficult period: he lost his job and his daughter Sunli would like to go abroad for her studies:

張三很遺憾他不能給孫儷錢。

Zhangsan regrets that he can't give money to Sunli.

\section{Embedded DP as the intended antecedent (Paragraph 3.3)}

(17a) 張三說的話讓人清楚了是無罪的。

Zhangsan's words let people understand that was innocent.

(17b) 孫儷是張三的妻子。一個月以前她被殺了。當警察聯繫張三時, 張三 證實自己在他妻子被殺的那天他在辦公室工作。也證實由於警察的聯 繫，張三才得知自己的妻子已經被殺害了：

Sunli is Zhangsan's wife. She was killed one month ago. Zhangsan testified that that day he was working in the office when the police contacted him. That's how he found out that his wife was dead:

張三說的話讓人清楚了是無罪的。

Zhangsan's words let people understand that _ was innocent.

(17c) 張三證明了宏亮的妻子被殺了的時候宏亮還在辦公室裡工作 :

Zhangsan testified that when Hongliang's wife was killed, Hongliang was still working in the office:

張三說的話讓人清楚了是無罪的。

Zhangsan's words let people understand that _ was innocent.

(18a) 張三說的話讓人清楚了他是無罪的。

Zhangsan's words let people understand that he was innocent.

(18b) 孫儷是張三的妻子。一個月以前她被殺了。當警察聯繫張三時, 張三 證實自己在他妻子被殺的那天他在辦公室工作。也證實由於警察的聯 繫，張三才得知自己的妻子已經被殺害了：

Sunli is Zhangsan's wife. She was killed one month ago. Zhangsan testified that that day he was working in the office when the police contacted him. That's how he found out that his wife was dead:

張三說的話讓人清楚了他是無罪的。

Zhangsan's words let people understand that he was innocent.

(18c) 張三證明了宏亮的妻子被殺了的時候宏亮還在辦公室裡工作 :

Zhangsan testified that when Hongliang's wife was killed, Hongliang was still working in the office:

張三說的話讓人清楚了他是無罪的。

Zhangsan's words let people understand that he was innocent. 


\section{First person intervenience in a topic chain (Paragraph 4)}

\subsection{First test}

(19) 張三說我以爲應該買一輛車。

Zhangsan said I think _ should buy a new car.

(20) 張三說我以爲他應該去買一輛車。

Zhangsan said I think he should buy a new car.

(21a) 張三說我認爲應該買一輛車。

Zhangsan said I think _ should buy a new car.

(21b) 我有一個在汽車經銷䍏工作的朋友。這個朋友告訴我張三的舊汽車壞 了，所以張三去過我朋友的綗店看了一下新的特斯拉汽車 :

I have a friend who works as a car dealer. This friend of mine told me that Zhangsan went there to have a look at the new Tesla car because his old car broke down:

張三說我認虍應該買一輛車。

Zhangsan said I think _ should buy a new car.

(21c) 昨天我告訴張三我的汽車壞了而且維修員說我的汽車太舊了，所以不 值得修了：

Yesterday I told Zhangsan that my car broke down, and the mechanic said that it is too old, so it's of no use to fix it at this point:

張三說我認爲應該買一輛車。

Zhangsan said I think _ should buy a new car.

(22a) 張三說我認爲他應該去買一輛車。

Zhangsan said I think he should buy a new car.

(22b) 我有一個在汽車經銷綗工作的朋友。這個朋友告訴我張三的舊汽車壞 了，所以張三去過我朋友的商店看了一下新的特斯拉汽車 :

I have a friend who works as a car dealer. This friend of mine told me that Zhangsan went there to have a look at the new Tesla car because his old car broke down:

張三說我認爲他應該買一輛車。

Zhangsan said I think he should buy a new car.

(22c) 昨天我告訴張三我的汽車壞了而且維修員說我的汽車太舊了，所以不 值得修了:

Yesterday I told Zhangsan that my car broke down, and the mechanic said that it is too old, so it's of no use to fix it at this point:

張三說我認爲他應該買一輛車。

Zhangsan said I think he should buy a new car.

4.2 Second test (after reviewing)

(23) 張三覺得我以爲應該買一輛車。

Zhangsan thinks I think should buy a new car. 
(24) 張三覺得我以爲他應該買一輛車。

Zhangsan thinks I think he should buy a new car.

(25) 張三覺得我認爲應該買一輛車。

Zhangsan thinks I think _ should buy a new car.

（26）張三覺得我認爲他應該買一輛車。

Zhangsan thinks I think he should buy a new car.

\section{Pro(noun)s sitting in the subject position of matrix clauses (Paragraph 3.5)}

\subsection{First test}

(27a) 張三陪他的兒子去影院看電影。很高興。 Zhangsan took his son to the cinema. _ is happy.

(27b) 張三上個星期生病了, 這件事兒讓他感覺難過。現在他痊癒了, 他終 於可以出去：

Zhangsan last week was ill, and this made him sad. Now he is recovered, and he can finally go out:

張三陪他的兒子去影院看電影。很高興。

Zhangsan took his son to the cinema. is happy.

(27c) 張三陪他的兒子去影院看電影。張三的兒子已經想去電影院很長時間 了, 可是張三以前太忙了。現在很高興。

Zhangsan took his son to the cinema. His son had been asking for it for a long time, but Zhangsan was too busy. Now is happy.

(27d) 張三的兒子沒通過英語考試。張三決定讓他的兒子高興 :

Zhangsan's son didn't pass the English exam. Zhangsan decided to cheer his son up:

張三陪他的兒子去影院看電影。很高興。

Zhangsan took his son to the cinema. _ is happy.

(28a) 張三陪他的兒子去影院看電影。他很高興。

Zhangsan took his son to the cinema. He is happy.

(28b) 張三上個星期生病了, 這件事兒讓他感覺難過。現在他痊癒了, 他終 於可以出去：

Zhangsan last week was ill and this made him sad. Now he is recovered and he can finally go out:

張三陪他的兒子去影院看電影。他很高興。

Zhangsan took his son to the cinema. He is happy.

(28c) 張三陪他的兒子去影院看電影。張三的兒子已經想去電影院很長時間 了, 可是張三以前太忙了。現在他很高興。

Zhangsan took his son to the cinema. His son had been asking for it for a long time, but Zhangsan was too busy. Now he is happy.' 
(28d) 張三的兒子沒通過英語考試。張三決定讓他的兒子高興：

Zhangsan's son didn't pass the English exam. Zhangsan decided to cheer his son up:

張三陪他的兒子去影院看電影。他很高興。

Zhangsan took his son to the cinema. He is happy.

5.2 Second test (after reviewing)

(29a) 張三陪他的兒子去影院看電影, 所以很高興。

Zhangsan took his son to the cinema, so _ is happy.

(29b) 張三上個星期生病了, 這件事兒讓他感覺難過。現在他痊癒了, 他終 於可以出去：

Zhangsan last week was ill, and this made him sad. Now he is recovered, and he can finally go out:

張三陪他的兒子去影院看電影, 所以很高興。

Zhangsan took his son to the cinema, so _ is happy.

(29c) 張三的兒子沒通過英語考試。張三決定讓他的兒子高興 :

Zhangsan's son didn't pass the English exam. Zhangsan decided to cheer his son up:

張三陪他的兒子去影院看電影, 所以很高興。

Zhangsan took his son to the cinema, so is happy.

(30a) 張三陪他的兒子去影院看電影, 所以他很高興。

Zhangsan took his son to the cinema, so he is happy.

(30b) 張三上個星期生病了, 這件事兒讓他感覺難過。現在他痊癒了, 他終 於可以出去：

Zhangsan last week was ill, and this made him sad. Now he is recovered, and he can finally go out:

張三陪他的兒子去影院看電影, 所以他很高興。

Zhangsan took his son to the cinema, so he is happy.

(30c) 張三的兒子沒通過英語考試。張三決定讓他的兒子高興：

Zhangsan's son didn't pass the English exam. Zhangsan decided to cheer his son up:

張三陪他的兒子去影院看電影, 所以他很高興。

Zhangsan took his son to the cinema, so he is happy.

(31) 張三知道了自己的兒子考上了斯坦福。很高興。

Zhangsan learned that his own son was admitted to Stanford. is very happy.

(32) 張三知道了自己的兒子考上了斯坦福。他很高興。

Zhangsan learned that his own son was admitted to Stanford. He is very happy. 


\title{
6. The interpretation of pro(noun)s in temporal adverbial clauses (Paragraph 4.1)
}

\author{
6.1 First test
}

(33a) 張三工作結束以後, 才能看電影。

When Zhangsan finishes his work, _ can watch a movie.

(33b) 張三的兒子想看電影, 但是張三正在做事而且他需要安靜 :

Zhangsan's son would like to watch a movie, but Zhangsan has things to do and needs silence:

張三工作結束以後, 才能看電影。

When Zhangsan finishes his work, __can watch a movie.

(34) 張三工作結束以後, 他才能看電影。

When Zhangsan finishes his work, he can watch a movie.

(34b) 張三的兒子想看電影, 但是張三正在做事而且他需要安靜 :

Zhangsan's son would like to watch a movie, but Zhangsan has things to do and needs silence:

張三工作結束以後, 他才能看電影。

When Zhangsan finishes his work, he can watch a movie.

(35) 工作結束以後, 張三才能看電影。

After finishing work, Zhangsan can watch a movie.

(36) 張三才能看電影, 工作結束以後。

Zhangsan can watch a movie, only after finishing work.

(37) 才能看電影, 張三工作結束以後。 can watch a movie, only when Zhangsan finishes his work.

6.2 Second test (after reviewing)

(38) 他工作結束以後, 張三才能看電影。

When he finishes his work, Zhangsan can watch a movie.

(39) 工作他結束以後, 張三才能看電影。

Lit: When work he finishes, Zhangsan can watch a movie.

(40) 能看電影, 在張三工作結束以後。 _ can watch a movie, when Zhangsan finishes his work.

(41) 能看電影, 在工作張三結束以後。

Lit: _ can watch a movie, when his work Zhangsan finishes.

（42）他能看電影, 在張三工作結束以後。 can watch a movie, when Zhangsan finishes his work.

（43）他能看電影, 在工作張三結束以後。

Lit: he can watch a movie, when his work Zhangsan finishes. 
(44) 張三能看電影, 在工作結束以後。

Zhangsan can watch a movie, only after finishing work.

(45) 張三能看電影, 在工作他結束以後。

Lit: Zhangsan can watch a movie, only after his work he finishes.

(46) 張三能看電影, 在他工作結束以後。

Zhangsan can watch a movie, only after he finishes his work.

(47) 我有很多工作要做, 可是現在我很忙。我叫張三做完我的工作 :

I have a lot of things to do, but now I am very busy. I ask Zhangsan to finish my work:

我工作結束以後, 張三才能看電視。

Lit: I, when finished working, Zhangsan can watch a movie.

\section{Conditional adverbial clauses (Paragraph 4.2)}

(48a) 孫儷如果能把魚都吃完, 會很高興。

Sunli, if _ can finish all the fish, _ will be happy.

(48b) 孫儷的女兒在休息時間吃的太多了。孫儷煮了魚 :

During the break, Sunli's daughter ate too much. Sunli cooked fish:

孫儷如果能把魚都吃完, 會很高興。

Sunli, if _ can finish all the fish, _ will be happy.

(49a) 孫儷如果她能把魚都吃完, 她會很高興。

Sunli, if she can finish all the fish, she will be happy.

(49b) 孫儷的女兒在休息時間吃的太多了。孫儷煮了魚：

During the break, Sunli's daughter ate too much. Sunli cooked fish:

孫麗如果她能把魚都吃完, 她會很高興。

Sunli, if she can finish all the fish, she will be happy.

(50) 如果能把魚都吃完, 孫儷會很高興。

If _ can finish all the fish, Sunli will be happy.

(51) 如果她能把魚都吃完, 孫儷會很高興。

If she can finish all the fish, Sunli will be happy.

(52) 孫儷會很高興, 如果能把魚都吃完。

Sunli will be happy, if _ can finish all the fish.

(53) 孫儷會很高興, 如果她能把魚都吃完。

Sunli will be happy, if she can finish all the fish.

\section{Concessive adverbial clauses (Paragraph 4.3)}

(54a) 孫儷雖然通過了高考, 但是還是不高興。

Sunli, although _ passed the university admission exam, _ is still not happy. 
(54b) 孫儷想讓她的女兒在南開大學學習。昨天孫儷的女兒通過了天津大學 醫學系的高考 :

Sunli would like her daughter to study at Nankai University. Sunli's daughter yesterday passed the test to enter the Medicine Department of Tianjin University:

孫轆雖然通過了高考，但是還是不高興。

Sunli, although _ passed the university admission exam, _ is still not happy.

(55a) 孫麗雖然她通過了高考, 但是她還是不高興。

Sunli, although she passed the university admission exam, she is still not happy.

(55b) 孫儷想讓她的女兒在南開大學學習。昨天孫儷的女兒通過了天津大學 醫學系的高考：

Sunli would like her daughter to study at Nankai University. Sunli's daughter yesterday passed the test to enter the Medicine Department of Tianjin University:

孫儷雖然她通過了高考，但是她還是不高興。

Sunli, although she passed the university admission exam, she is still not happy.

(56) 孫儷想讓她的女兒在南開大學學習。昨天孫儷的女兒通過了天津大學 醫學系的高考：

Sunli would like her daughter to study at Nankai University. Sunli's daughter yesterday passed the test to enter the Medicine Department of Tianjin University:

雖然她通過了高考，但是她還是不高興。

Although she passed the university admission exam, she is still not happy.

(57) 孫儷想讓她的女兒在南開大學學習。昨天孫儷的女兒通過了天津大學 醫學系的高考 :

Sunli would like her daughter to study at Nankai University. Sunli's daughter yesterday passed the test to enter the Medicine Department of Tianjin University:

雖然通過了高考，但是她還是不高興。

Although _ passed the university admission exam, she is still not happy.

(58a) 孫儷還不高興，雖然通過了高考。

Sunli is still not happy, although _ passed the university admission exam.

(58b) 孫儷想讓她的女兒在南開大學學習。昨天孫儷的女兒通過了天津大學 醫學系的高考 :

Sunli would like her daughter to study at Nankai University. Sunli's daughter yesterday passed the test to enter the Medicine Department of Tianjin University:

孫儷還不高興，雖然通過了高考。

Sunli is still not happy, although _ passed the university admission exam. 
(59a) 孫儷還不高興，雖然她通過了高考。

Sunli is still not happy, although she passed the university admission exam.

(59b) 孫儷想讓她的女兒在南開大學學習。昨天孫儷的女兒通過了天津大學 醫學系的高考 :

Sunli would like her daughter to study at Nankai University. Sunli's daughter yesterday passed the test to enter the Medicine Department of Tianjin University:

孫麤還不高興, 雖然她通過了高考。

Sunli is still not happy, although she passed the university admission exam.

\author{
Mara Frascarelli \\ Mailing address: University of Roma Tre, Via Ostiense, 236, 00146 Rome, Italy \\ Email: \\ mara.frascarelli@uniroma3.it \\ Marco Casentini \\ Mailing address: Sapienza University of Rome, Circonvallazione Tiburtina, 4, 00185 Rome, \\ Italy \\ Email: \\ marco.casentini@uniroma1.it \\ Received: June 7, 2018 \\ Accepted: $\quad$ January 22, 2019
}




\title{
空主語在激進空主語語言中的解釋 : 漢語的主題鏈與話語語義的要求
}

\author{
Mara Frascarelli' ${ }^{1}$, Marco Casentini ${ }^{2}$ \\ 羅馬第三大學 ${ }^{1}$ 、羅馬智慧大學 ${ }^{2}$
}

\section{摘要}

根據在線調查收集到的原始數據, 本文章證明了漢語空主語的解釋依賴於 Frascarelli $(2007,2018)$ 的話題準則 (Topic Criterion), 由此空主語參數意味著解釋的 信息 - 結構策略。然而, 激進空主語語言 (radical pro-drop languages) 表現出對明顯 與局部話題的高度選擇性。本選擇性被歸因於最小顯性鏈接 (minimal overt link) 的 語法和語音的界面條件。此外, 本研究還分析了狀語從句的結構差異。條件與時間 從句有非限定性關係從句的屬性, 但是讓步從句是在補語語域 (C-domain) 內合朔 的從句, 或在分裂屈折語 (split-TP) 內合俰的從句。有關分歧歸因於算子的存在, 同時因爲它們的設定參照系功能 (frame-setters), 狀語從句在主句之前。

\section{關鍵詞}

關於型 - 傳喚型話題, 空主語, 激進空主語, 主題鏈, 狀語從句 